\title{
Survey for The Conservation of Agrobiodiversity in Three Italian Linguistic (Occitan, Croatian and Franco-Provençal) Islands.
}

\author{
Gaetano Laghetti (Corresponding author) \\ CNR - Institute of Plant Genetics, Bari, Italy \\ Tel: 00-39-80-5583400Ｅ-mail: gaetano.laghetti@igv.cnr.it
}

\begin{abstract}
Giovanni Ghiglione
CNR - Institute of History of Mediterranean Europe, Genoa, Italy

E-mail: giovanni.ghiglione@lettere.unige.it
\end{abstract}

Antonino De Lisi

CNR - Institute of Plant Genetics, Bari, Italy

E-mail: antonino.delisi@igv.cnr.it

Gina Maruca

CNR - Institute of Plant Genetics, Bari, Italy

E-mail: gina.maruca@igv.cnr.it

Francesco Losavio

CNR - Institute of Plant Genetics, Bari, Italy

E-mail: francescopaolo.losavio@igv.cnr.it

Domenico Pignone

CNR - Institute of Plant Genetics, Bari, Italy

E-mail: domenico.pignone@igv.cnr.it 


\author{
Karl Hammer \\ Former Institute of Crop Science, University of Kassel, Witzenhausen, Germany \\ E-mail: khammer.gat@t-online.deummary
}

Received: July 29, 2012 Accepted: August 11, 2012

doi:10.5296/jbls.v4i1.2147 URL: http://dx.doi.org/10.5296/jbls.v4i1.2147

\begin{abstract}
This study is a continuation of a research started in 1996 to study and safeguard the agrobiodiversity in Italian linguistic islands by the Institute of Plant Genetics of the C.N.R. of Bari (Italy) and the Institute of Crop Science of Kassel University (Germany). In 2011 additional three collecting missions were carried out in the Franco-Provençal, Croatian, and Occitan linguistic areas. In all 146 accessions were collected belonging mainly to landraces of cereals, pulses and vegetables. Even if these linguistic areas still conserve worthy crop genetic resources (e.g. rye and wheat in Occitan districts, common beans in Franco-Provençal villages of Apulia region), a strong genetic erosion of the most typical crops was recorded. Safeguarding these crops both ex situ and in situ is thus a matter of urgency.
\end{abstract}

Keywords: Agricultural biodiversity, Occitan, Croatian, Franco-Provençal, genetic erosion, Italy, linguistic islands, conservation

\title{
1. Introduction
}

A research program to study and safeguard the agrobiodiversity in Italian linguistic islands by Institute of Plant Genetics (IGV) of the National Research Council (CNR) of Bari (Italy) and the Institute of Crop Science of Kassel University (Germany) started in 1996. To this purpose, several exploration and collecting missions were carried out in: a. Italian towns of Albanian origin (Hammer-Spahillari et al., 2007, Hammer et al., 2011, Laghetti et al., 1998, 2011); b. the German-speaking areas of northern Italy (Hammer et al., 2007a, 2007b, Laghetti et al., 2003, 2007); c. a Slavic Community in the Italian Alps (Miceli et al., 2007); d. two Griko-speaking areas in southern Italy (Laghetti et al., 2008); e. the Ladin linguistic areas and a first part of the Occitan ones (Laghetti et al., 2012). The main results of this research recorded a strong genetic erosion of the most typical crops cultivated in the studied linguistic areas and the serious and urgent necessity of their safeguarding.

In 2011 additional three collecting missions were carried out in the Franco-Provençal, Croatian, and Occitan linguistic areas located in Italy.

\section{Methodology}

In October-November 2011 the agricultural areas of the two Franco-Provençal towns sited in 


\section{Aacrothink}

Apulia, the three towns of Croatian origin of Molise (Fig. 1), and the most important municipalities of Occitan origin (Fig. 2) not covered in 2010 (Laghetti et al., 2012) were investigated. The main aims of this research were to find and collect accessions of autochthonous crop genetic resources together with information on local agrobiodiversity, ethnobotany, genetic and phenotypic variation, and degree of genetic erosion.

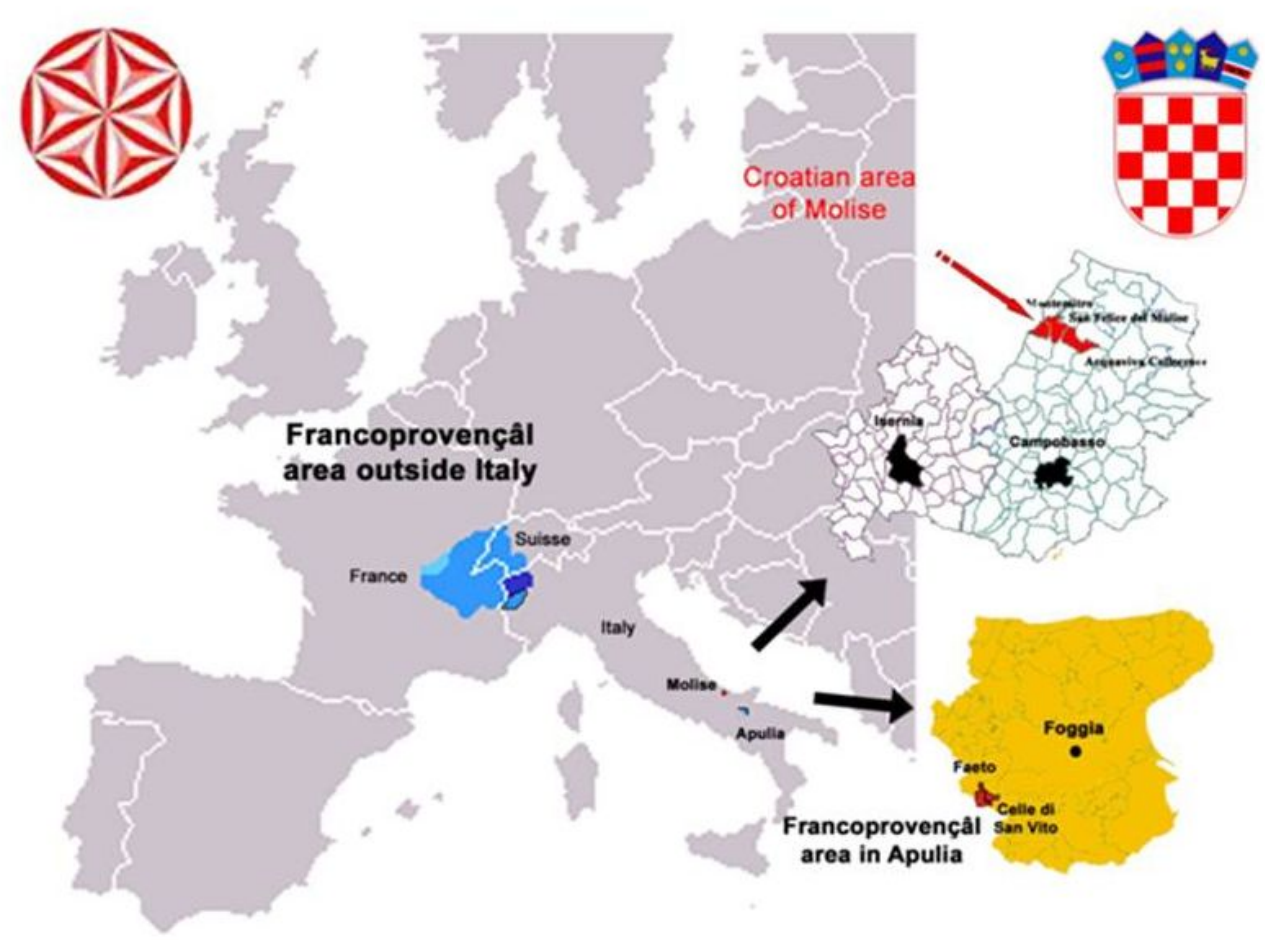

Figure 1. The Franco-Provençal and Croatian linguistic areas located in Italy 


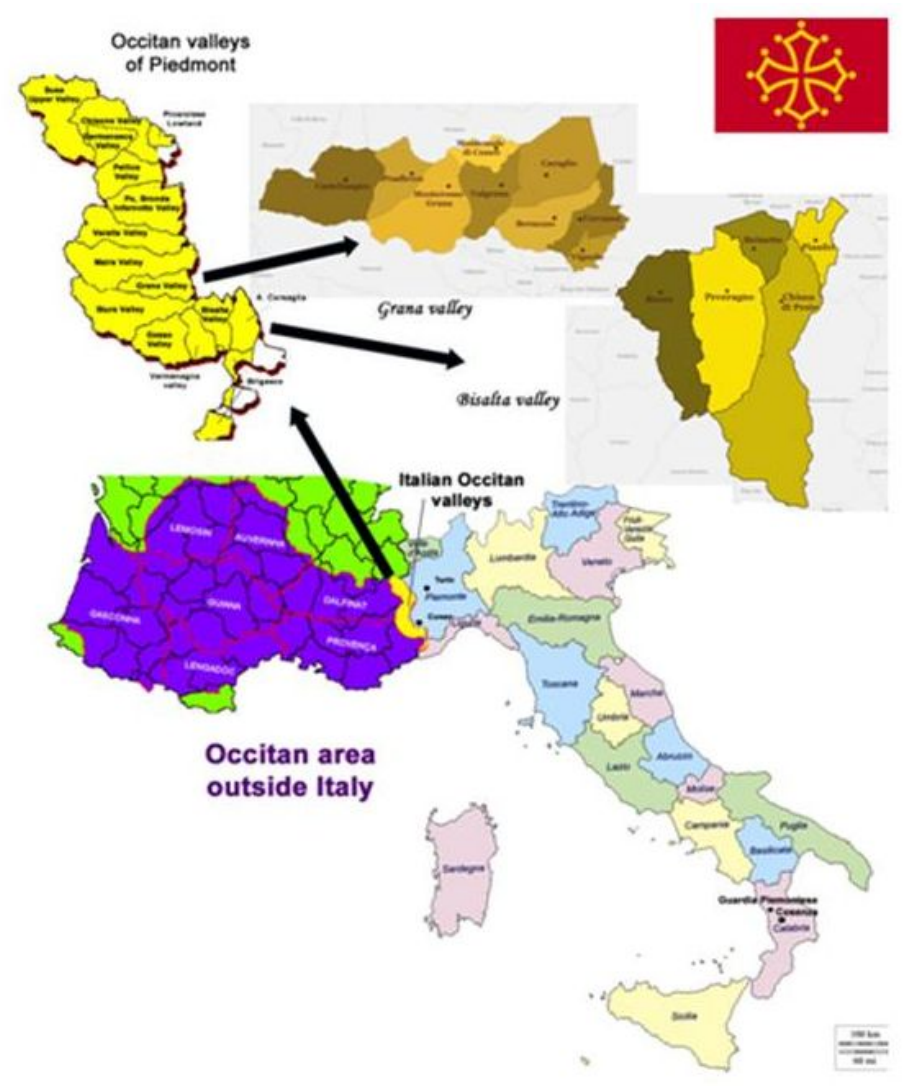

Figure 2. The Occitan linguistic areas studied in the mission of 2011

Usually the collecting strategy is established on an ecological basis, using a large grid for each homogeneous area and randomly selecting the sites to be visited. In the case of small areas to be investigated (e.g. small islands), if possible, this criterion can be replaced by an almost complete census of all farms present on the territory. During the present mission the exploration team followed both principles, e.g. the 'complete census' at small villages of Guardia Piemontese and Celle San Vito, and the 'homogeneous areas' for the Occitan valleys in Piedmont. The source of this material came principally from cultivated fields and farmers stocks and, occasionally, from uncultivated places. Collecting material was mainly seed and fruit samples. When seeds were not available living plants were gathered and put inside plastic containers with a little bit of water inside for keeping the moisture, with roots wrapped with moist paper. In this way an easy transport was possible for one to two weeks.

More details on our sampling strategies and use of modern exploration tools (e.g. GPS and GIS systems), are reported elsewhere (Hammer et al., 1991, Laghetti et al., 1998, Perrino et al., 1981).

\section{Results and Discussion}

In all, 146 accessions belonging to 44 taxa were collected. The detailed list of the sampled material is reported in Table 1.

\subsection{FRANCO-PROVENÇAL AREA}

In Italy the Franco-Provençal linguistic area (present also in France and Switzerland) is 
mainly located in several mountain valleys of Piedmont and 'Valle d'Aosta' regions (north Italy) (Fig. 1). In Apulia (south Italy) a Franco-Provençal minority resides in the two small towns of 'Celle di San Vito' (the smallest municipality in Apulia: 173 inhabitants in 2010; 726 m.a.s.1.) and Faeto (866 m.a.s.l., the highest municipality in Apulia; 643 inhabitants in 2010), and it is one of the least known in Italy.

The question of the origin of this community has never been fully elucidated. Surely, it dates from the Middle Ages. The ancestors of this linguistic community may have been Angevin soldiers provisionally allocated in the area, or persecuted Waldenses religious: their exact origin is still a debated question (Gilles, 1643; De Salvio, 1908; Melillo, 1959, 1974).

The Franco-Provençal area in north Italy was partially explored in 1991 during a general collecting mission not specifically focused on linguistic areas (Laghetti et al., 1993). Also the Franco-Provençal area in Apulia was crossed in the past during the several collecting missions by IGV-IPK teams (Hammer et al., 1992) but it was never the subject of a specific study.

In the two municipalities of Faeto and 'Celle di San Vito' the use of Franco-Provençal language is still alive and it has been, in recent times, recognized by the Italian State (the Law 482 of 15.12.1999 has recognized the protection of linguistic minorities in Italy, including the Franco-Provençal minority). Remarkable is the fact that in the eighties of the last century there were, though few in number and especially among the elderly population, still some monolingual speakers. This phenomenon is closely related to geographic isolation that has characterized these two municipalities for a long time and passed, partially, only in recent times. Nowadays, the younger segment of the population considers the two local dialects (the Franco-Provençal and the Apulian one) as an entity increasingly uncomfortable in their work and they are ready to forget them (unlike what happens in the Franco-Provençal areas in North Italy). In general, the number of speakers of Franco-Provençal has been declining significantly. According to UNESCO, Franco-Provençal is a 'potentially endangered' language in Italy and an 'endangered' language in Switzerland and France. There are also efforts to preserve the Franco-Provençal cultural heritage of Apulian municipalities. The awareness of endangered and state recognition in the 1990s are part of this attempt. On the other hand, the demographic decline of the two existing communities seems unstoppable.

The main source of income for the population of Faeto continues to be made up by agriculture, based on cultivation of cereals (especially wheat), forages, vegetables and olives; the breeding of cattle, pigs, sheep, goats, horses and poultry is also practiced. Famous are the feasts of pork (in February) and ham (in August). The industrial activities, limited to the food, construction and wood, are almost insignificant and very modest is the presence of the tertiary sector, which consists of the commercial network (but not significant enough in size to meet the basic needs of the community).

In this area 43 accessions were collected of which 8 cereals, 19 pulses and 16 vegetables (Table 1). In the past the most cultivated cereals were wheat, barley, oat and maize as many sources testify, e.g. the local ethnographic museum, old farmers, some reports as that one by Pastore Nicola (published online at: 


\section{Ml Macrothink}

Journal of Biology and Life Science

ISSN 2157-6076

2013, Vol. 4, No. 1

www.comune.faeto.fg.it/Upload/cms/.../lavoroagricolo_ita.pdf), remains of old water mills (Pirozzoli and Pirozzoli, 1983).

During the mission only landraces of maize were found while those ones of other cereals have been replaced in time by new varieties. The eight populations of maize collected were very variable for the morphology and colour (red and yellow) of cobs. The red types have a later ripening time than the yellow ones. The seeds to be used for sowing were stored not loose but inside their cobs (Fig. 3A).
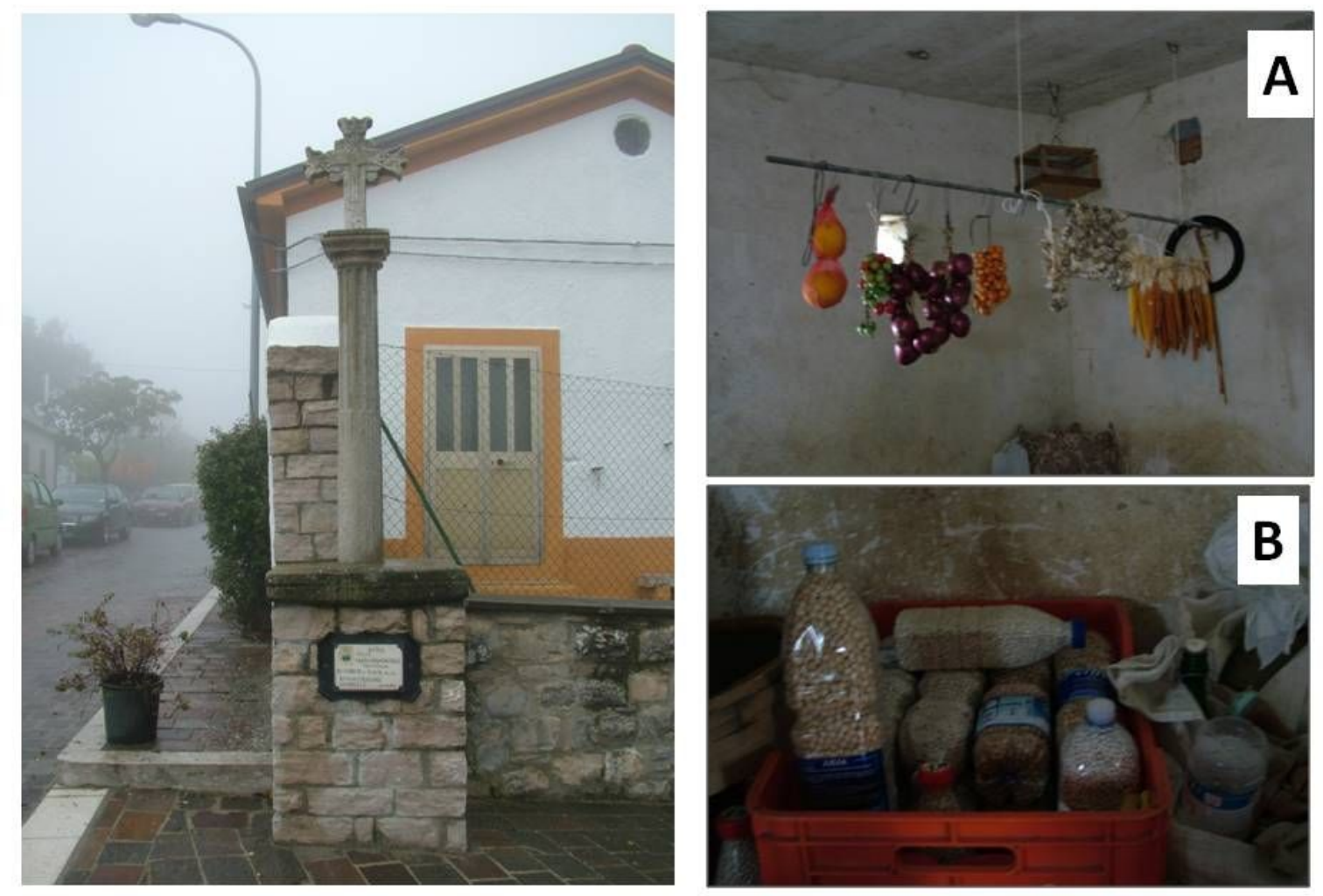

Figure 3. 'Celle di San Vito' the smallest municipality in Apulia, with a storage room of local vegetables (A) and plastic containers for seeds of pulses (B)

The maize (Zea mays) cultivation was intensive. The seeds were planted at a distance of $15-20 \mathrm{~cm}$ and were alternated with seeds of common beans. 'Lu pezzùche' is a particular tool used for husking. It was usually made from the horns of billy goats; sometimes pointed wooden twigs of dogwood (Cornus mas L.) or blackberry bush or even a large nail were also used. When the cobs were ripe farmers proceeded to their beating using a very special tool, the flail (compare Laghetti et al., 2002 p. 59). It consisted of two sticks of wood different in length, thickness and quality of wood (in some areas are called the 'short' and the 'long') linked together by a strip of leather. The longer and thinner stick, (named 'manfanile' or 'manfano') was of light wood such as beech or ash, the shorter and thicker stick (named 'vetta') was of hardwood such as oak. Usually cobs were used to light the fire but sometimes as stoppers for bottles, too. The leaves were not thrown, on the contrary, were used to form a kind of mattress (named 'saccùnne') to put under the wool mattress in order to make the bed 
softer and reduce the moisture coming up from the floor. Often it happened that many people offered their free labor for husking of corn to get its leaves.

In the past not all farmers owned the fields they were working. In most cases, they were tenants who had to, therefore, pay the land owner. Formerly there was the misery for local farmers. The seed of wheat for sowing was borrowed from rich landowners that for each quantity lent, farmers had to bring back two. Traditionally in the area, sowing of cereals began in late September starting with oat. The plot of land was divided into smaller parts called 'pòreche'. This division was made to spread the seed evenly. The 'pòreche' were different in size, depending on the type of seeds. The seeds, especially those of wheat, were sieved with sieves to remove any impurities and select only the best ones. Then they were washed in large vats and dried in the sun, and finally, a few days before sowing, they were mixed with a solution of water and 'piéra turchìne' ('blue stone', a copper-based mineral) that made them inedible seeds by birds as well as preventing it became black and unusable for planting.

Oat was harvested first, then barley, then wheat, and finally the' Marzuolo' (a durum wheat sowed in spring). The entire surface of the dry yard was cleaned with a broom made of branches of Spartium junceum L.

Even in times past the crop rotation was used: after a cereal, a legume crop followed or the land was left to fallow (called 'maggese') and be used to collect hay for animal feed. The old farmers say that by doing so, the land was rested and vent all the weeds. The hay was sometimes planted, mainly with the sainfoin (Onobrychis viciifolia Scop.) and vetch (Vicia sativa L.). The hay-cutting took place in May-June, when the grass had become hard, but had not yet contaminated the soil with their seeds.

In the peasant culture of Faeto however, the 'maggese' word indicated most of all a field not cultivated with cereals, but with legumes such as beans, chickpeas, broad beans, grass peas, lupins, all plants that have the ability to fix nitrogen. The 'maggese' was considered in the Faeto tradition as the kitchen garden of the house, where they planted a variety of plants, whose fruits were used as sustenance for the family.

Among the 19 pulses collected there were 10 common beans, 5 chickpeas, 2 lentils and 2 broad beans.

In the area two qualities of broad beans (Vicia faba L. var. faba, large seeds) are cultivated: one for human consumption and in this case, the seeds are planted in the furrow, the other ones, used for animal feed, sown by broadcasting. When those planted for food reach the height of $10 \mathrm{~cm}$, they are earthed up with the hoe, giving them fresh soil and nutrients. When matured, they are cut and dried in the field, then, are beaten with a stick. During the winter, in Faeto, it was common to see players in the cellars nibbling roasted broad beans and drinking wine.

Some old landraces of chickpeas were found. This crop is considered by local farmers as a tough plant and, usually, it is cultivated in family gardens. The harvest takes place in July. The plants are uprooted and gathered in small bunches. Once dried on the plant, the pods can 
be beaten with a stick along the branches or separated from the plants and then beaten.

Ten populations of the well known common bean 'fagiolo di Faeto' (Phaseolus vulgaris L.) were sampled. Usually they are grown next to maize and gathered in the early morning when there is dew in order to avoid the splitting up of the pods. This pulse was considered the 'meat of the poor'. In the area the best soils for growing common beans is in the quarter of Vetruscelli.

In the past a pulse rarely cultivated was the grass pea (Lathyrus sativus L.). Today this crop has almost disappeared. It required the worse land, its seeding was done by broadcasting and its cultivation did not require special care. It was mowed with the scythe and its harvest was very difficult because the plants enveloped between them. The seeds were used to obtain 'corn flour' for animals.

Sixteen (16) landraces of vegetables were sampled of which: onion (1), beet (1), turnip (Brassica rapa L. subsp. rapa) a rare crop in south Italy (Fig. 4C), pepper (3), melon (1), cucumber (1), zucchini (2) (Cucurbita pepo L.), rocket (1), lettuce (1), tomato (1) called 'pizzutiell', basil (1), parsley (1) and corn salad (1) [Valerianella locusta (L.) Laterrade] (Table 1).

Table 1. Number of accessions collected

\begin{tabular}{|c|c|c|c|c|c|c|c|}
\hline \multirow[t]{2}{*}{ CROPS } & \multirow[t]{2}{*}{ ORIGIN } & \multirow{2}{*}{$\begin{array}{c}\text { FRANCO-PROVENÇAL } \\
\text { AREA }\end{array}$} & \multirow{2}{*}{$\begin{array}{l}\text { CROATIAN } \\
\text { AREA }\end{array}$} & \multicolumn{2}{|c|}{ OCCITAN AREA } & \multirow{2}{*}{$\begin{array}{l}\text { OTHER } \\
\text { AREAS }\end{array}$} & \multirow[t]{2}{*}{ TOTAL } \\
\hline & & & & PIEDMONT & $\begin{array}{c}\text { GUARDIA } \\
\text { PIEMONTESE }\end{array}$ & & \\
\hline Avena sativa & $\mathrm{P}$ & - & 1 & - & - & 1 & 2 \\
\hline $\begin{array}{l}\text { Fagopyrum } \\
\text { esculentum }\end{array}$ & $\mathrm{P}$ & - & - & 1 & - & - & 1 \\
\hline $\begin{array}{l}\text { Hordeum } \\
\text { vulgare }\end{array}$ & A & - & 1 & - & - & 1 & 2 \\
\hline $\begin{array}{l}\text { Secale } \\
\text { cereale }\end{array}$ & $P$ & - & - & 2 & - & - & 2 \\
\hline $\begin{array}{l}\text { Triticum } \\
\text { aestivum }\end{array}$ & A & - & - & - & - & 2 & 2 \\
\hline $\begin{array}{l}\text { Triticum } \\
\text { durum }\end{array}$ & A & - & - & - & - & 1 & 1 \\
\hline $\begin{array}{l}\text { Triticum } \\
\text { spelta }\end{array}$ & A & - & - & 2 & - & - & 2 \\
\hline Zea mays & $\mathrm{N}$ & 8 & 1 & 2 & - & 1 & 12 \\
\hline Cereals & & 8 & 3 & 7 & - & 6 & $\underline{24}$ \\
\hline $\begin{array}{l}\text { Cicer } \\
\text { arietinum }\end{array}$ & $\mathrm{P}$ & 5 & 1 & - & - & 7 & 13 \\
\hline $\begin{array}{l}\text { Lablab } \\
\text { purpureus }\end{array}$ & $\mathrm{N}$ & - & - & - & - & 1 & 1 \\
\hline Lathyrus & A & - & - & - & - & 1 & 1 \\
\hline
\end{tabular}




\begin{tabular}{|c|c|c|c|c|c|c|c|}
\hline sativus & & & & & & & \\
\hline $\begin{array}{l}\text { Lens } \\
\text { culinaris }\end{array}$ & A & 2 & - & 1 & - & 3 & 6 \\
\hline $\begin{array}{l}\text { Phaseolus } \\
\text { coccineus }\end{array}$ & $\mathrm{N}$ & - & - & 2 & - & - & 2 \\
\hline $\begin{array}{l}\text { Phaseolus } \\
\text { lunatus }\end{array}$ & $\mathrm{N}$ & - & - & 1 & - & - & 1 \\
\hline $\begin{array}{l}\text { Phaseolus } \\
\text { vulgaris }\end{array}$ & $\mathrm{N}$ & 10 & - & 8 & 1 & 27 & 46 \\
\hline $\begin{array}{l}\text { Pisum } \\
\text { arvense }\end{array}$ & A & - & - & - & - & 2 & 2 \\
\hline $\begin{array}{l}\text { Vicia faba } \\
\text { major }\end{array}$ & A & 2 & - & - & - & - & 2 \\
\hline $\begin{array}{l}\text { Vicia faba } \\
\text { minor }\end{array}$ & $\mathrm{A}$ & - & 1 & - & - & 1 & 2 \\
\hline $\begin{array}{l}\text { Vigna } \\
\text { unguiculata }\end{array}$ & A & - & - & 1 & - & - & $\mathbf{1}$ \\
\hline Pulses & & 19 & 2 & 13 & 1 & 42 & $\underline{77}$ \\
\hline Allium сера & A & 1 & - & - & - & - & 1 \\
\hline $\begin{array}{l}\text { Allium } \\
\text { sativum }\end{array}$ & $\mathrm{A}$ & - & - & 1 & - & - & 1 \\
\hline Beta vulgaris & $\mathrm{E}$ & 1 & - & - & - & - & 1 \\
\hline $\begin{array}{l}\text { Brassica } \\
\text { oleracea }\end{array}$ & $\mathrm{E}$ & - & - & - & - & 2 & 2 \\
\hline $\begin{array}{l}\text { Brassica rapa } \\
\text { subsp. rapa }\end{array}$ & $\mathrm{E}$ & 1 & - & - & - & 1 & 2 \\
\hline $\begin{array}{l}\text { Capsicum } \\
\text { annuиm }\end{array}$ & $\mathrm{N}$ & 2 & - & 1 & - & 1 & 4 \\
\hline $\begin{array}{l}\text { Capsicum } \\
\text { frutescens }\end{array}$ & $\mathrm{N}$ & 1 & - & - & - & - & 1 \\
\hline $\begin{array}{l}\text { Cucumis } \\
\text { melo }\end{array}$ & $\mathrm{A}$ & 1 & - & - & - & - & 1 \\
\hline $\begin{array}{l}\text { Cucumis } \\
\text { sativus }\end{array}$ & $\mathrm{P}$ & 1 & - & 1 & 1 & 2 & 5 \\
\hline $\begin{array}{l}\text { Cucurbita } \\
\text { moschata }\end{array}$ & $\mathrm{N}$ & - & - & - & - & 1 & 1 \\
\hline $\begin{array}{l}\text { Cucurbita } \\
\text { pepo }\end{array}$ & $\mathrm{N}$ & 2 & - & 1 & 1 & 1 & 5 \\
\hline Cucurbita sp. & - & - & - & - & - & 1 & 1 \\
\hline Eruca sativa & A & 1 & - & - & - & - & 1 \\
\hline $\begin{array}{l}\text { Lactuca } \\
\text { sativa }\end{array}$ & $\mathrm{A}$ & 1 & - & 1 & - & - & 2 \\
\hline
\end{tabular}




\section{Macrothink}

Journal of Biology and Life Science

ISSN 2157-6076

2013, Vol. 4, No. 1

\begin{tabular}{|c|c|c|c|c|c|c|c|}
\hline $\begin{array}{l}\text { Lycopersicon } \\
\text { esculentum }\end{array}$ & $\mathrm{N}$ & 1 & - & 2 & 1 & 1 & 5 \\
\hline $\begin{array}{l}\text { Ocimum } \\
\text { basilicum }\end{array}$ & A & 1 & - & - & - & - & 1 \\
\hline $\begin{array}{l}\text { Petroselinum } \\
\text { crispum }\end{array}$ & $\mathrm{A}$ & 1 & - & - & - & - & 1 \\
\hline $\begin{array}{l}\text { Solanum } \\
\text { aethiopicum }\end{array}$ & $\mathrm{N}$ & - & - & - & - & 1 & 1 \\
\hline $\begin{array}{l}\text { Solanum } \\
\text { melongena }\end{array}$ & $\mathrm{P}$ & - & - & 1 & 1 & - & 2 \\
\hline $\begin{array}{l}\text { Valerianella } \\
\text { locusta }\end{array}$ & $E$ & 1 & - & - & - & - & 1 \\
\hline Vegetables & & 16 & - & 8 & 4 & 11 & $\underline{39}$ \\
\hline $\begin{array}{l}\text { Anethum } \\
\text { graveolens }\end{array}$ & $\mathrm{P}$ & - & - & - & - & 1 & 1 \\
\hline $\begin{array}{l}\text { Citrullus } \\
\text { lanatus } \\
\text { subsp. } \\
\text { citroides }\end{array}$ & $P$ & - & - & 1 & - & - & 1 \\
\hline $\begin{array}{l}\text { Lagenaria } \\
\text { siceraria }\end{array}$ & $\mathrm{P}$ & - & - & - & - & 1 & 1 \\
\hline $\begin{array}{l}\text { Medicago } \\
\text { lupulina } \\
\text { (wild) }\end{array}$ & $\mathrm{E}$ & - & - & 1 & - & - & 1 \\
\hline $\begin{array}{l}\text { Pimpinella } \\
\text { anisoides } \\
\text { (wild) }\end{array}$ & $\mathrm{E}$ & - & - & - & - & 2 & 2 \\
\hline $\begin{array}{l}\text { Other } \\
\text { species }\end{array}$ & & - & - & 2 & - & 4 & $\underline{6}$ \\
\hline Total & & $\underline{43}$ & $\underline{5}$ & $\underline{30}$ & $\underline{5}$ & $\underline{63}$ & $\underline{\underline{146}}$ \\
\hline
\end{tabular}

Legend: A: old crop plants (Archeophytes); P: later introduced crop plants (Palaeophytes); N: newly introduced crop plants (Neophytes); E: local crop plants. 

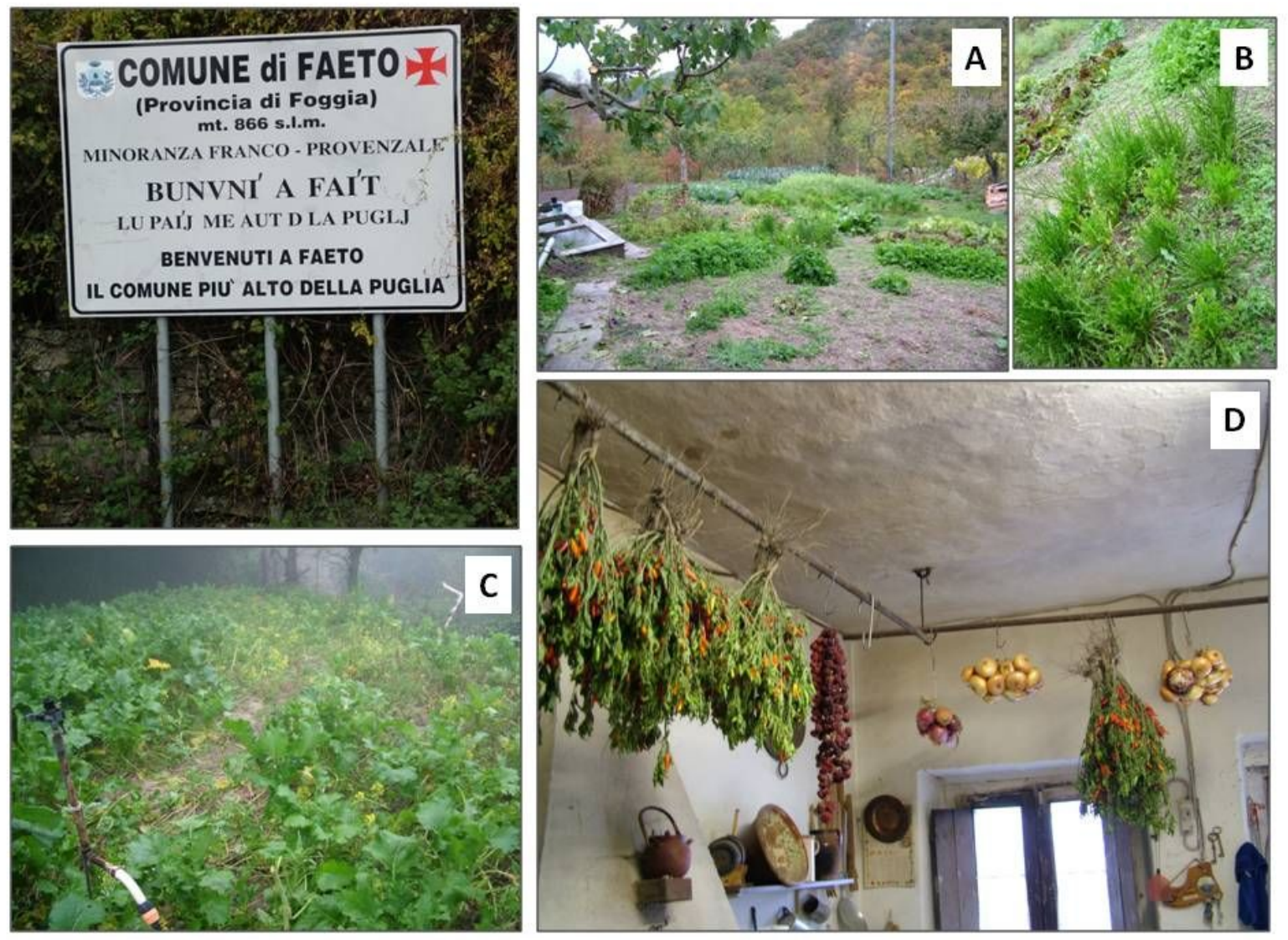

Figure 4. Faeto the highest municipality in Apulia (866 m asl) with a typical vegetable garden (A). In it many crops are cultivated as oak leaf lettuce (B), turnips both for roots ('rapa') and for flower stalks ('cima di rapa') (C), and then stored in traditional way (D)

Another vegetable that has played a significant economic importance for the farmers of Faeto and 'Celle di San Vito' is potato. It is a renewing crop and has the distinction of leaving the ground under the best conditions for the cultivation of cereals. In the 'Difesa' district of Faeto there was a large-scale cultivation of potatoes, so that at the end of the 1960s a cooperative of farmers was formed for their cultivation and marketing, but it did not have great success. Traditionally in January, the soil is prepared with deep plowing and spreading of manure; in late February, early March, farmers proceed to planting tubers. They plant potatoes of all sizes, the too big ones are cut into several pieces to save material. Then the young plants are topped up with a hoe when the amount of land is sufficient, if not the wooden plough double bar is used. Ploughing is done in the midst of two furrows so that both the furrow of the right and of the left are topped up. Before flowering, which occurs in May, the plants are treated with copper sulphate to combat mildew. The harvest takes place in September, when the farmer has finished all the other jobs. The hoe is used for the disinterment, but often the tubers are damaged, because no one knows exactly where they are in the ground, so it farmers have switched to using the wooden plough with a wing. The farmers have also tried a plough with holed wings, in such a way that the earth would pass between the holes of the plough and the potatoes hurled at the side; but there is a drawback constituted by the fact that the 


\section{MInstitute Math $_{\text {int }}^{\text {Macrothing }}$}

Journal of Biology and Life Science ISSN 2157-6076 2013, Vol. 4, No. 1

smaller potatoes are lost. For this reason the use of this tool has been abandoned.

\subsection{CROATIAN AREA}

Today in the Molise region (Fig. 5) there are three towns inhabited by a Croatian ethno-linguistic minority: Montemitro (Mundimitar in Croatian; 460 inhabitants in 2010; 508 m.a.s.1.), 'Acquaviva Collecroce' (Kruč in Croatian; 697 inhabitants in 2010; 425 m.a.s.1.) and 'San Felice del Molise' (Filič in Croatian; 706 inhabitants in 2010; 546 m.a.s.1.) (Fig. 1). However, colonization by Croatian refugees is also historically established for other towns of Molise such as Palata, Tavenna, Mafalda, 'San Biase', 'San Giacomo degli Schiavoni', Montelongo and Petacciato, although only Montemitro, 'Acquaviva Collecroce' and 'San Felice del Molise' still preserve the language, customs and costumes of the lineage of origin (Perillo, 1985).

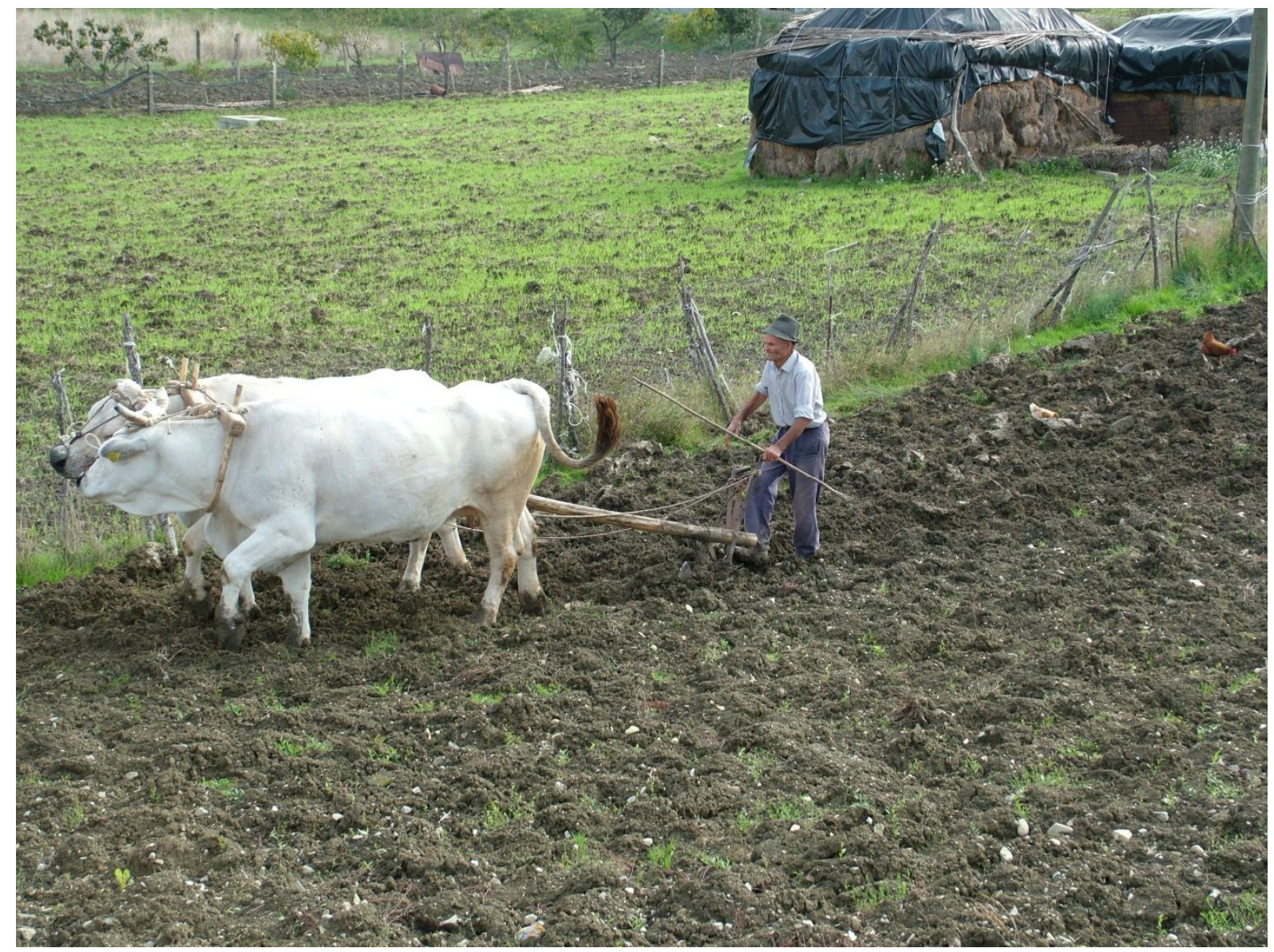

Figure 5. In Molise it is still possible to find a traditional agriculture not yet mechanized. Also the values of E.I. (ethnobotanicity index) for this region are considered amongst the highest in Italian areas (Guarrera et al., 2008).

The language spoken by local people is essentially the ancient language of the Croatian-type štòkavo ìkavo, in use in central Dalmatia, in the Croatian hinterland and in Herzegovina. According to some studies, it would be a language preserved for about 400 years, with a countenance eminently practical, because it was spoken mainly by farmers; as a matter of fact abstract words are almost absent (Breu, 1990). The ancient Croatian language is today used 
mainly in the family context and interpersonal relationships. It has been transmitted for five centuries only by oral tradition and, indeed, there are no traces of writings, apart from some poems.

The first documented contacts of Slavs from the other side of the Adriatic off the coast of Molise, which we have certain documentation, occurred in the early thirteenth century, for economic, commercial and cultural reasons. The first commercial treaty between the Marine Republic of Ragusa in Dalmatia and the small port of Termoli in Molise dates back to March 1203.

There is no doubt that the most consistent waves of immigration occurred after the famous defeat at Kosovo in 1389, better known in Italian history as the 'Battaglia del campo dei merli' (Battle of the field of blackbirds), which marked the defeat of Christian armies and the progressive expansion of the Ottomans in the Balkan Peninsula with the consequent exodus of Slavs and Albanians to the Italian peninsula. With the conquest of Constantinople in 1453, the Turks began their expansion into northern territories inhabited by Slavs. As already happened to the Albanians a few decades earlier; since the sixteenth century, new migrations were originated from the Turks. The Republic of Venice and the Kingdom of Naples facilitated settlements along the Adriatic coast to repopulate those lands abandoned as a result of the huge earthquake of 1456 and the Plague of 1495. The weakness of the Republic of Venice allowed the Aragonese, already present in the Kingdom of Naples, to extend their influence to the Adriatic side, but at the same time encouraged the Turkish expansion. The unstoppable advance of Turks transformed into a real exodus that was a sequenced emigration. To encourage settlement of Slavs, and in consideration of their poverty, the Aragonese king granted to the immigrants of the Kingdom of Naples some privileges, such as halving of taxes for a period of fifty years. Although, in the absence of archival records it is not possible to pinpoint the date of the arrival of Slavic refugees in Molise, scholars consider the late fifteenth century by both linguistic and numismatic reasons. In fact, while in Molise almost all of the terms to indicate crops in Croatian are present, the Croatian names are completely lacking for some foods spread rapidly in Europe after the discovery of America (such as potatoes, tomatoes, maize, etc.).

The Croatian minority almost always rebuilt and repopulated ancient villages, abandoned because of earthquakes and plagues. This is the case of 'Acquaviva Collecroce' that, if indeed existed in the same place at the end of the thirteenth century, should have depopulated as a result of different events and, then, was repopulated by refugees from Croatia, between the fifteenth and sixteenth centuries. These people came directly from both Dalmatia and the neighboring village of Cerritello, where Albanian and Slav settlers already lived together. The only settlement surely founded by the Croatian population is the town of 'San Giacomo degli Schiavoni'. Before 1880 it was very hard to reach the Croatian villages of Molise, simply because there were no roads! (Rešetar, 1911). It is understandable, therefore, that until then this minority community has been able to maintain the integrity of their cultural and linguistic identity. On 5 November 1996 in Zagreb a treaty was signed between the Italian Republic and the Republic of Croatia (then made executive by Law no. 129 of April 23, 1998), in which Italy formally recognized the ethnic and linguistic Croatian minority of Molise. More details 


\section{Macrothink}

about the history of this linguistic area are given by Rešetar (1911).

Agriculture was the first work to which Croatian immigrants were devoted when they reached the Molise region (Piccoli, 2009). They, paying the due tithes, cultivated only crops that the Commanders of the Knights of Malta, local feudal lords, authorized by the 'Capitulars' (old type of contract/agreement). In the early days, along with the cultivation of cereals, Croatian farmers were devoted to sheep farming and breeding of various species of livestock.

During the mission for this study area, a general abandoning of agriculture was recorded (Fig. 6) and, consequently, a strong genetic erosion of local crops (Fig. 7).

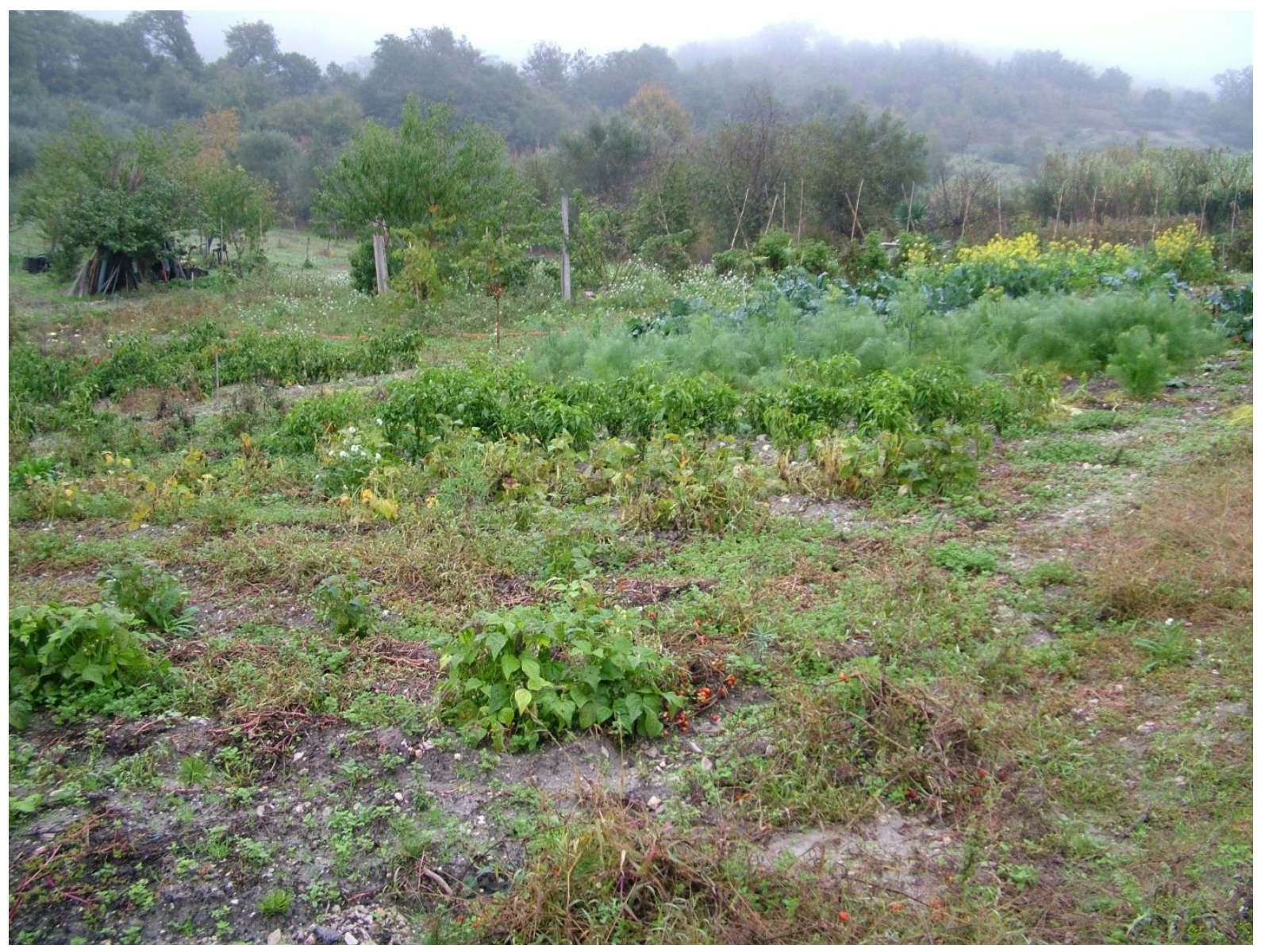

Figure 6. One of the very few vegetable gardens still cultivated at Montemitro 

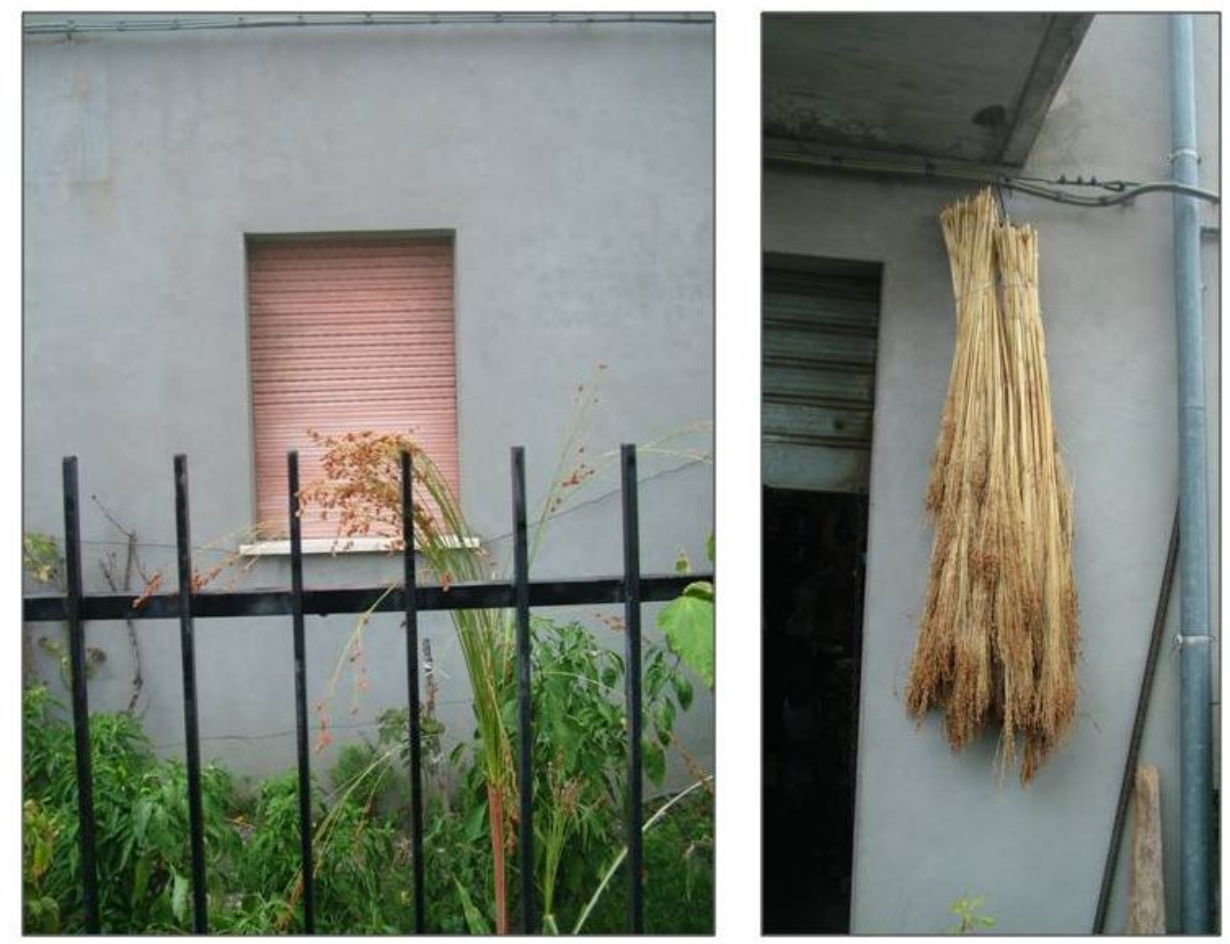

Figure 7. A traditional race of sorghum (Sorghum saccharatum convar. technicum (Koern.)

Tzvel.) still used for the production of brooms in the area of Montemitro

Wheat ('žita' in local language) is one of the oldest cereals grown by Croatian immigrants. Details about the varieties used is a difficult task to find but, according to a specific research by Piccoli (2009), in the XVIII century the 'Cacavon' variety of durum wheat (Triticum durum Desf.) (characterized by a flat bleu spike with black awns) and the bread wheat ( $T$. aestivum L.) variety 'Sulima' (with a long and laciniate spike) were cultivated. In the XIX century the 'new' durum wheat variety 'Saragolla' started to be grown in the area. Around 1930 's the durum wheat variety 'Cappelli' and the bread wheat variety 'Trinesa' selected by the 'Istituto Selettivo Strampelli' were introduced into local cultivation. Today only new cultivars are cultivated.

The cultivation of barley (Hordeum vulgare L. - 'zimac') and oat (Avena sativa L. - 'ovas') was much easier than that of wheat. They were sown at the same time (autumn) as wheat and the fields did not need to be prepared. Oat was used mainly as feed ('zob') for horses and mules when they did heavy work. Barley, as well as the broad beans (Vicia faba L.), were useful to fatten pigs. The new varieties of barley and oats are very rare in this area while some of the old landraces are still cultivated and two of these were collected during the mission (Table 1).

Maize ('granja') was and is another important local cereal. It is sown in spring and harvested at the end of August or at the beginning of September. One landrace was sampled (Table 1).

Only two landraces of cicer (Cicer arietinum L. - 'čič') and broad beans were found. Broad beans ('bob') were the most common pulse locally grown and some landraces are still present; in particular those with large seeds have almost disappeared, while those with small seeds 
have survived because more suitable for mechanical sowing (usually in October).

Flax (Linum usitatissimum L. - 'lan') was another typical old crop grown (only) in the past (starting from XVI century) together with hemp ('kanavala') that was introduced in these zones (from the Naples area) two centuries later than flax. These two crops were sown in small fields of ca. $100 \mathrm{~m}^{2}$ enough for a family in one year. Their cultivation ended after 1950 's because of the use of modern fibers such as cotton and nylon.

An important local fruit tree is olive tree (Olea europaea L. - 'maslina'). According to Piccoli (2009), when the first Croatian immigrants arrived in the area they found only some scattered plants and only around the XVII century the first small plantations appeared. At that time local people used it for cooking mainly pork fat, suet ('ndzonja') and lard ('mast'). Olive oil was used very little because its extraction was difficult for them.

Among the most traditional fruit trees grown in this linguistic island grape (Vitis vinifera $\mathrm{L}$. 'loza') is probably the oldest. As a matter of fact this crop was already cultivated in the XVI century soon after the arrival of first Croatians. This was due to the fact that they were forced by their Commanders to plant vineyards.

Together with other fruit trees (e.g. figs) another plant greatly used traditionally was the oak (Quercus spp. - 'dub'). This tree is very widespread in the area and centennial plants produced a number of acorns ('željud'), very good as feed for pigs. Its wood ('hrast') was also very precious, excellent as firewood and for building tools and barrels to store wine.

Additional data on the traditional food and herbal uses of wild plants in the Slavic community of Molise can be found in Di Tizio et al. (2012). Worthy information to compare the ethnobotanical knowledge of Croatian people living in Molise with that of Istria is reported by Pieroni et al. (2003) and Pieroni and Giusti (2008).

\subsection{Occitan area}

The Piedmont mountain area was densely populated during the fifties of the last century, but, later on, most of the Occitan valleys have been subject to a process of depopulation, with rates among the highest of all the Western Alps. A general introduction to Occitan areas inside and outside Italy is reported in Laghetti et al., (2012). In 2010, a first preliminary mission was carried out. In that investigation Maira valley and Gesso valley in the Piedmont region, and part of territory of Triora village in the Liguria region were visited. In Laghetti et al., (2012), a review about the ethnobotanical studies and on agrobiodiversity carried out in Occitan areas inside Italy is reported.

In 2011 the exploration team focused mainly on Grana valley, Bisalta valley, Maira valley (in areas not covered by the 2010 mission) and Stura valley in the Piedmont region, and 'Guardia Piemontese' town (in the Calabria region, south Italy) (Fig. 2).

About the Occitan areas visited in Piedmont in 2011, they are characterized by a complex rural landscape with a long and ancient pastoral and agricultural tradition. Here life was and is very difficult and requires enormous sacrifices on the population, given the harshness of the territories and the morphological, geographical and historical diversity of these 
environments typically Alpine and Mediterranean mountain. In the XIX century, serious food shortages and famine caused emigration with consequent widespread abandonment of rural mountain areas in favour of the cities and the most promising centers of the coast. The orographical situation of the southernmost part is characterized by mountains close to the coast with steep ridges. The only solution to the problems of soil erosion and to get arable soils that prevailed from time immemorial, was that of the artificial terraces. They consist in a series of walls supported by dry stones, built with a technique not easily assimilable transmitted over the centuries by generations and that has characterized the local landscape (Ghiglione and Leone, 2001, Ghiglione, 2005, Ghersi and Ghiglione, 2012). According to the different zones the terraces were built with the same construction technique but with different shapes and materials depending on local available resources. They have also different names: usually 'fasce' in Liguria, 'faissa' in Provence and 'òucho' in Provencal Alps.

\subsubsection{Occitan area (Piedmont)}

\subsubsection{The Flora in the mountain zone of Cuneo.}

The naturalistic importance of the mountain area around Cuneo - also testified by the presence of three Natural Parks - derives primarily from the great variety of plant species and the rarity of some of them, not forgetting, of course, animals housed in the various valleys. The richness of the flora is due to - especially as regards the more southern areas (i.e. 'Liguri' and 'Marittime' Alps), to the geographical location and geological history. The more northern valleys ('Grana', 'Maira', 'Varaita' and 'Po') are characterized by less botanical richness although, in some cases, we found characteristic taxa of the central Alps, in some areas not certainly elective. Indeed, in the southernmost part of the Alps of Cuneo, the proximity of the sea and the presence of warm currents coming from it enable the spread of typical Mediterranean species (e.g. cysts, brooms, lavenders, etc.) in areas and altitudes unusual for them, while the alpine climate favors the descent of alpine species at latitudes that are their southern limit. This web of different climatic conditions so different thus determines the existence of large areas of overlapping between species with different habitats and at times even opposed.

Rainfall decreases generally from southeast to northwest and increases steadily with altitude, especially on slopes facing north. Likewise, the summer thunderstorm rain-squalls tend to be located more on the same slopes. In the north, the valleys have been faced - particularly in the summer semester, both day and night - with permanent stationing nebulosity that provides the vegetation significant moisture, thus promoting the rapid growth of beech (Fagus sylvatica L.), silver fir (Abies alba Mill.) and green alder [Alnus viridis (Chaix) DC.].

To the south of the mountain chain, however, precipitation and cloudiness decreased markedly, so that most of the plant populations assume a xerophilous and Mediterranean character. In addition, special microclimates are present that favor the establishment of a number of endemics. As generally known, the Alps - from their formation until today underwent deep climatic changes and, in particular, those caused by major glaciations of the Quaternary that, for their extension, led to almost total destruction of the primitive alpine vegetation. The Marittime Alps, in the whole, for their southern and peripheral location, 
almost entirely escaped with this cataclysm. The glaciers while descending into the valleys, left extensive open spaces in which plant life continued in an undisturbed way, thus archaic species survived, evolved with the lifting of the Alps or which come here from a distant past. Species destroyed by glaciation in the rest of the Alps could thus survive, while others continued their evolutionary life. The old species, endemic ones that originated here and others (arrived here after long migrations) can now be found in conditions of very rare relics, now without any evolutionary ability or opportunity for geographic expansion. It is clear that the Marittime Alps, during glaciation, became major 'areas of refuge'. Among the most precious and rare endemic species, the following are worth mentioning: Berardia subacaulis Vill. (Compositae), Helianthemum lunulatum (All.) DC. (Cistaceae), Phyteuma cordatum Balbis (Campanulaceae), and Saxifraga florulenta Moretti (Saxifragaceae), representing relics of an ancient vegetation of the Cenozoic era, almost completely disappeared and thus real 'living fossils'.

3.3.1.2 Historical notes on agriculture in the southern Piedmont Occitan valleys to the border with Liguria

In these areas, from the XIX century, we have only subsistence farming, with cultivation mainly of vegetables and cereals for bread together with cultivation of chestnuts (Castanea sativa Mill. - called 'bread-tree') for chestnut flour instead of wheat flour. Chestnut flour for centuries has replaced the bread made with cereals most of all during period of famine. Throughout the Middle Ages the peasants of the mountains, from where the altitude permitted it, used to collect chestnuts. This species dates mostly from the Middle Ages and spread in the XVI century replacing the old forest that consisted of beech, fir and oak trees (Quaini, 1983, p. 147). According to the local census of 1531, we know that the mountain area of Triora was the only territory that produced a surplus of cereals for bread and even chestnuts; also Casalis (1842) described this area very rich in pulses, potatoes, hay, barley, rye, oat, walnuts and apples. In other more marginal areas wheat, requiring more care and producing little, began to be replaced by other cereals of lower quality but more robust and with secure yield, e.g. rye, barley, oat, emmer, millet, foxtail millet, sorghum, and spelt. Rye became very important for centuries to feed the poorest of the population even if the Latins considered it 'bad grass'. Pliny considered rye 'very bad, good only to ward off hunger'. In ancient times a dramatic problem was the ergot, probably, the main reason that labeled rye as 'bad grass'. Ergot (Claviceps purpurea (Fr.) Tul. (Ascomycetes) is due to a poisonous fungus that grows on the ear and is easily visible and forms a kind of dark brown horn 1 or $2 \mathrm{~cm}$ long. Formerly, during the harvest, ergot was not easily visible and farmers did not give much importance to this different color of the grain so that it was milled together with good seeds. In the past people did not know of the toxicity of this fungus that was eaten and caused many victims. Later, the toxic effects of this fungus were well studied and it was used as folk remedy to contract the uterus of women. Nevertheless, throughout the Middle Ages until about 50 years ago, rye was cultivated in the mountains. In many areas where agriculture was possible as a result of forest clearance this crop became the most widely grown cereal ever. Virgil had already noticed that rye 'born on any type of soil yielded a hundredfold, and itself is a fertilizer'. More robust than wheat, rye grows at higher altitudes reaching 1000 m.a.s.1.. Taller 
than wheat it suffers from lodging; a typical agro-technique to solve the problem in these areas consisted in the insertion of beech or hazel branches in these fields, as is still done today. The sowing of the so called 'barbarià' (in Provencal), a mixture of rye with other cereals (Montanari, 2000), was also characteristic.

In the countryside, however, wheat-bread was missing and Chabrol (1994) confirms that the food is various along the coast where it was possible to eat very well, while soups and polenta prevail inland. For such food preparations, barley, oats and millets were suitable, often boiled to make 'pulimenta', recalling the image of a pot hung from the ceiling over the fireplace in the middle of the kitchen. This mash of cereals, legumes and vegetables, was seasoned by the meat, when available, or by lard or olive oil. The farmers preserved pork or sheep meat, their most bred animals, together with wild game meat, especially wild boars and deer that were drying in the smoke or put under salt (Montanari, 2000). Stouff (1970) believes that in 1400 there was not a Provencal cuisine as lard is, used as a seasoning for soups, and olive oil has a limited use to cook the eggs or fish.

The statistical survey of Chabrol, prefect of Napoleon at Montenotte Department, states in the years from 1806 to 1812, the production of 'segalata' (the same as 'barbarià' or 'barbariato' or 'méteil') and rye amounting to 5,230 tons in the surroundings of Ceva village, while the corn in the same district reaches 5,955 tons. Corn, pulses and oats follow in the order of quantity; very high was the production of hay meadows (Chabrol, 1994). In the territory of Ceva, which includes the southern Langhe, Chabrol (1994) informs that a two-year rotation was practiced, alternating wheat and corn or wheat and legumes, without fallow. The lands around this district were not very fertile and the average ratio between harvest and sowing is 5 to 1 . In the neighborhood of Ceva, Chabrol detected the 8,241 acres of arable land, of which 3,722 sown with wheat, 3,269 with 'segalata' and rye, 640 with corn, 444 with vegetables, and 166 with oats.

\subsubsection{Bisalta valley}

Boves, Peveragno and Chiusa Pesio are the main municipalities in Bisalta valley. The local dialect shows influences of the 'Piemontese' language. The lexical basis of the rural vocabulary remains Occitan. In the nineteenth century these three towns were centers of industrial activity: spinning-mills, potteries, wool-mills, kilns, tanneries and factories for the extraction of tannin. Today all the three towns are culturally vibrant, with associations involved in the rediscovery of local traditions, social activities and history. In fact, this is especially noticeable in the problem of genetic erosion of local crops. The task of recovery and safeguard was given to the 'CReSO Consortium', an entity consisting of the Piedmont Region, the Piedmont Provinces but also from organizations of fruit growers and horticulturists. The CReSO also actively collaborates with the University of Turin and its genebank. A list of old traditional vegetables of these areas with notes on their characteristics, recovery and exploitation is reported by Baudino et al. (2011).

The territory is very interesting from a naturalistic point of view e.g. the Natural Park 'Alta Valle Pesio e Tanaro' rich of rare plants (Fig. 8) and characterized by the presence of the wolf. On a hill near the Garelli refuge (900 m.a.s.l.) there is a botanical station dedicated to the 


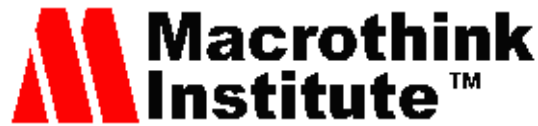

Journal of Biology and Life Science ISSN 2157-6076 2013, Vol. 4, No. 1

scholars Clarence Bicknell and Emile Burnat. The station is home to a wetland, with specimens of Drosera spp. and Pinguicula spp., carnivorous plants of the Alps. Half an hour from there is a second botanical station, placed near a small lake below the imposing walls of Marguareis mountain (2651 m.a.s.l.). There the beautiful orchid (Cypripedium calceolus L.) grows, taken as the symbol of the Park.
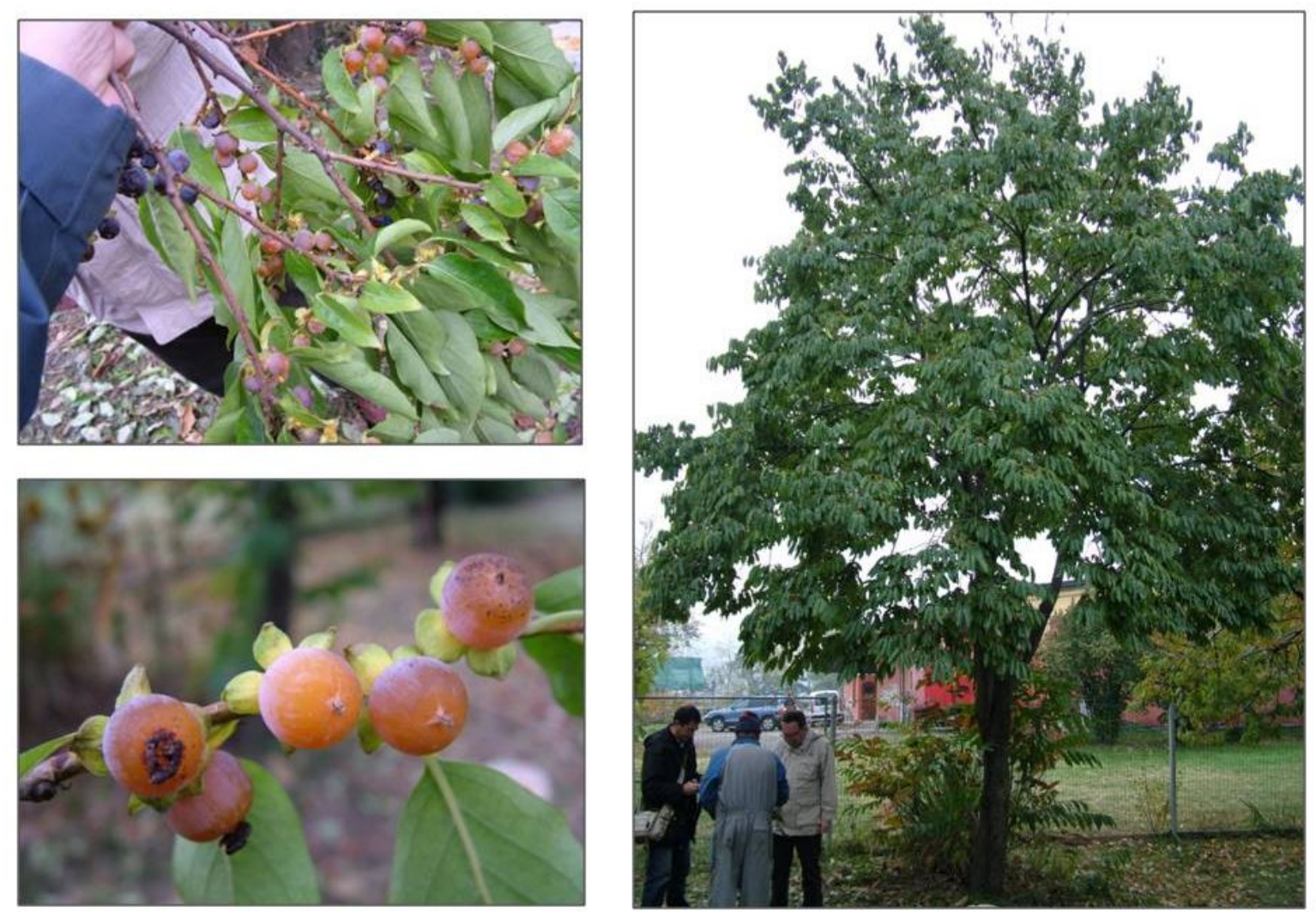

Figure 8. A rare specimen of Diospyros lotus L. in the area mostly grown as a grafting stock for kaki (D. kaki Thunb.) [Borgo San Dalmazio, Boves]

At Boves (Buèves in Occitan) there is a museum dedicated to the chestnut tree, which, in the past, had so much importance in the livelihood of the population of these areas. The museum was created as part of an international project to exploit this fruit.

\subsubsection{Maira Valley}

Casalis (1842) in his monumental work on the 'Maira valley' writes: 'ascending from Dronero to S. Damiano, the valley offers lush appearance to the eyes with its fruitful chestnuts, green vineyards and blond cereals'. He also lists as products of the bottom of the valley wheat, potatoes, chestnuts, walnuts, hay, maize, hemp, grape, and mulberry trees, while in the higher regions above S. Damiano products of the soil are reduced to a small amount of wheat, rye, oats, 'formentone' (buckwheat) and potatoes. Casalis also stresses that local oat is of good quality and, being in high demand, it is exported to Piedmont and that many vineyards are cultivated up to Stroppo village but not in higher areas. 


\section{MInstitute Macrothink $_{\text {Int }}$}

Journal of Biology and Life Science ISSN 2157-6076 2013, Vol. 4, No. 1

Hemp (Cannabis sativa L. - 'l chinebbu in Occitan), grown until a few decades ago, has been an important resource in the local mountain economy (Rey, 2006). This plant originated in Central Asia and spread to Europe in about 100 B.C. (Zohary and Hopf, 1988). In Italy it was first introduced by the Celts to the lower Po valley, then to Piedmont and later rapidly in the Alpine valleys (Rey, 2006). In these Occitan valleys the role of the women was very significant; they took care of the house, fields, animals, often alone because men emigrated in search of work. Women were largely entrusted with the cycle of hemp processing, from sowing to typing, from spinning to packing of valuable items (Fig. 9).

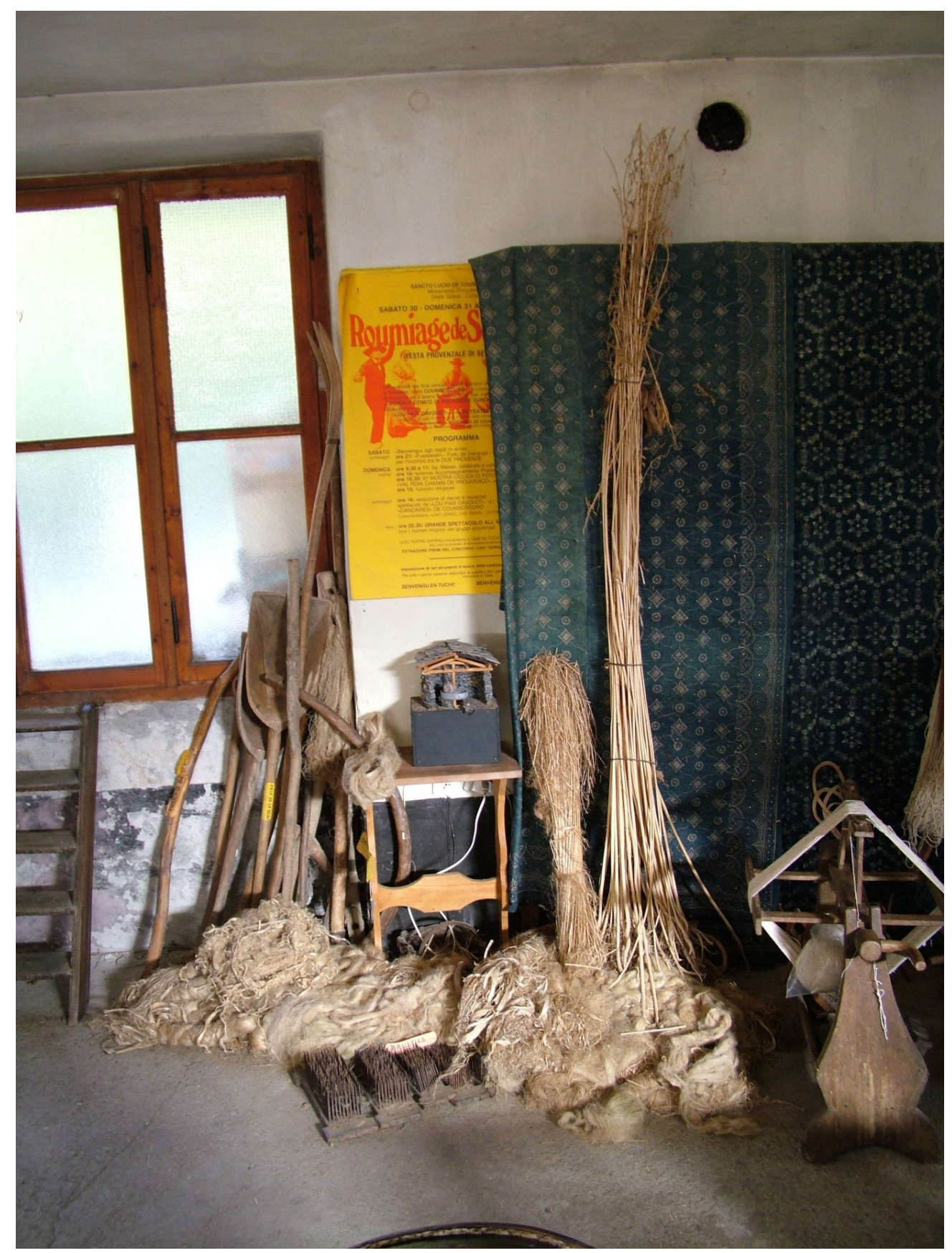

Figure 9. Old tools for the processing of hemp [Ethnographic Museum at 'Sancto Lucio de Coumboscuro' in Grana valley] 
Casalis (1842) mentiones the wealth of local forests as huge larch and fir trees that are cut to be transported by the waters of Maira, the large wild game of the mountains, as the tasty trouts of the rivers, the renowned local butter, various types of cheese, wool, the manufacture of canvas and sickles, in particular in Dronero. Despite the wealth of this valley, Casalis notes that 'the poor products of agriculture and industry were not enough to sustain the needs of the many villagers. It so happened that many of them went away from their homes, migrating to the surrounding provinces of Piedmont and France to carry on the mercantile and trafficking'.

\subsubsection{Grana Valley}

The name of this valley comes from the Latin 'Vallis granis' ('Valley of wheat'), due to the abundance and quality of wheat produced in the plane in the bottom of the valley. In the past four mills worked in the area, so important for this cereal, that in the coat-of-arms of Valgrana town three wheat spikes are depicted (Aimar, 1978).

In 1700 the breeding of silkworms was widespread in this valley to involve almost all the rural families especially in the lower valley and the plain below. Almost 4000 plants of mulberry (Morus alba L.) were grown in the valley and their leaves (locally called 'mureri') were used as fodder for silkworms. Three varieties of mulberry were present: i) 'i selvatici' (the wild types), ii) 'i domestici' (the domestic types), iii) 'i moscatelli' (muscatel types) (Isoardi, 2008). Unfortunately in June of 1958 this activity ended, after that had contributed much to alleviate the poverty of many families.

Formerly other important local crops were: i) raspberry (Rubus idaeus L.), introduced in the valley from France in 1959-60. The gold period was from 1970-75 to 1985 but later, for many reasons, its cultivation became not more economically convenient and ended. ii) the typical and renowned "fagiolo di Valgrana" common bean (Isoardi, 2008), together with the other following landraces: "fagiolo del re", "fagiolo della regina di Valgrana" and "fagiolo della carne".

The Grana valley, protected by the Marittime Alps and the Cozie Alps, has always been synonymous with unpolluted territory, an environmental niche protecting a unique 'green' treasure, studied by eminent naturalists in time. Details on the natural vegetation of Grana valley can be found in Mondino (1965). The valley, located in the western part of the Province of Cuneo, is home to eight towns: Vignolo, Cervasca, Caraglio, Valgrana, Montemale, Monterosso, Pradleves and Castelmagno. A population of shepherds and farmers, carefully hidden in the woods, has worked actively over time, leaving a heritage of great architectural and landscape value. The mountain tourism is one of the new forms of income in this area.

Formerly in the Grana valley farmers cultivated potatoes, common and naked barley, but not good for bread making (Casalis, 1842). The cultivations described by Casalis and related primarily to an agriculture for food, persisted almost up to 1950s. Then, since the 1960's, a radical social change started, when many people turned away permanently from the mountains to the plains, to reside and work in factories of the cities of Cuneo and Turin. In some rare cases ancient crops (e.g. rye, fruit trees) have been rediscovered, serving in part to 


\section{MInstitute ${ }^{\text {Mink }}$}

rebuild the historic agricultural landscape of mountain areas. The old landraces of rye with two caryopsis per spikelet have been replaced by new varieties of triticales.

In addition to rye, spring wheat (Triticum aestivum L.) was grown in Grana Valley. The cultivation started at 670 m.a.s.l. and extends up to Castelmagno at 1700 m.a.s.l.. Spring wheat to make bread flour was sown at the end of April and harvested in late July and early August. Traditionally barley was and is sown when the 'cherry blossoms fall'. Two types of barley are grown, covered and naked. The former is given to the animals, while the later called 'orzo mondo', is used to make bread. Spelt (T. spelta L., locally called 'farro') was also cultivated here.

Typical local fruits are the apple "mela di Val Grana" and the more famous "Madernassa" pear (Fig. 10). This pear is a spontaneous landrace, probably derived from a natural cross between a wild pear with 'Martin Sec' variety. It was subsequently often preferred just to the 'Martin Sec' for higher and more stable yield, also for some similar organoleptic traits as a certain flavor and harshness on the palate, if eaten raw. In the Grana Valley, the "Madernassa" pear was introduced in regular orchards in the early 1940s. Since then it has adapted so well to the local environment, so as to be able to combine both the landscape and the agricultural economy. The characteristic "Madernassa" orchards now extend across the lower and middle valley. As always, the main center of production is Valgrana town, where every year there is also a popular festival dedicated to this fruit. About $80 \%$ of the current 66 hectares are cultivated with organic farming methods. The "Madernassa" pear has always been known and used mainly as a cooking pear, exquisite in the composition of cakes and desserts. In recent years its valuable typicity found the interest of researchers of ancient tastes and remained intact in the tradition of the area. In addition this pear is also highly requested by the new important commercial channel of the industrial processing of quality, especially for the production of fruit salads, organic juices and organic purée mainly for German market.
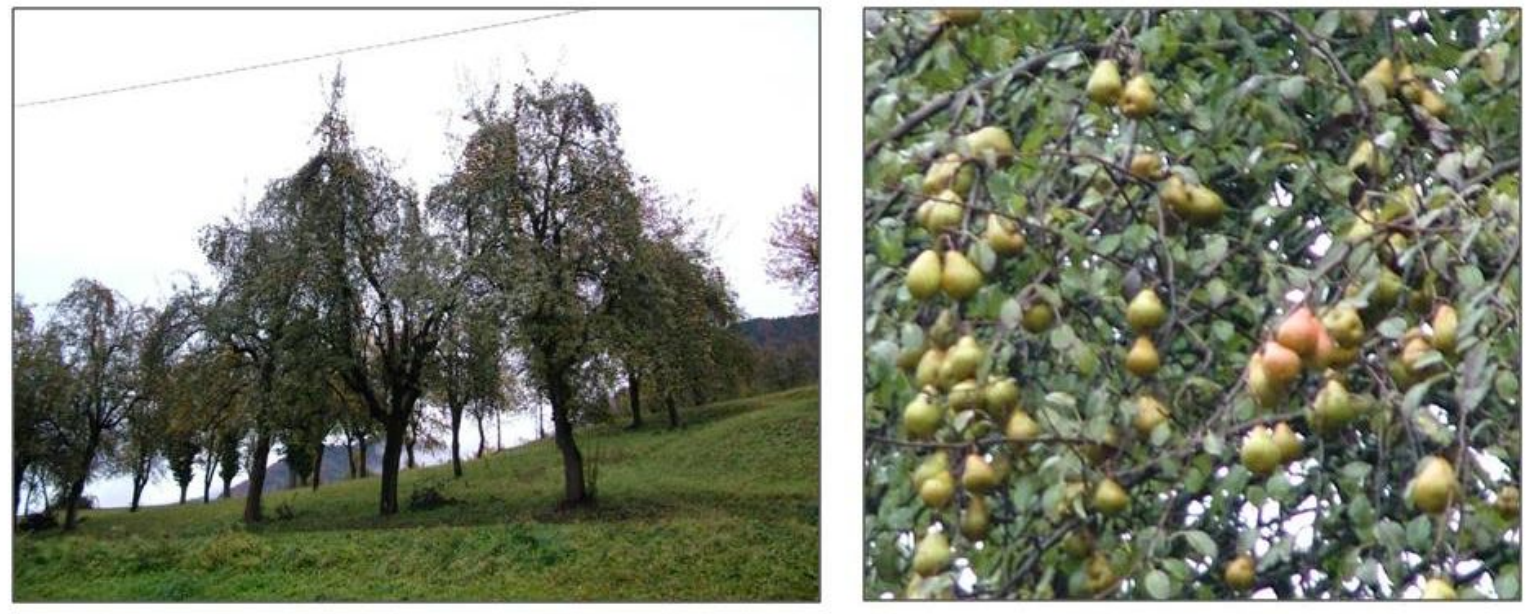

Figure 10. The "Madernassa" pear a typical old variety used mainly as a cooking pear [Valgrana town]

Very important in these Alpine valleys, is the cultivation of forage for livestock, most of all 
polyphyte meadow. Sheep begin to climb the ancient mountain paths in late May, while the herds of cows follow in late June. In the high mountain shelters during the summer the fine alpine cheese (called 'formaggio d'alpeggio') is made. 'Castelmagno PDO (Protected Designation of Origin)' is the king cheese produced in Val Grana made with cow's milk, supplemented with small amounts of sheep and goat milk, in precise proportions as alchemical secret guarded by the manufacturer and derived from the experience of ancient tradition.

In the district of Coumboscuro people speak the Alpine Provençal variant of the 'langue d'oc', or more precisely 'north-Occitan Delfinese', as defined by the specialists. Its geographical area reaches from the basin of the Durance north of Sisteron to the mountainous region, bordering the Po river Basin south of Susa. This large family of talk covers, in addition to the valley of the Po river, a dozen tributary valleys, including Blins (Bernard, 1992, van Gennep, 1990). In the past at Coumboscuro among the traditional cereals (except maize, not growing here) cultivated in the valley, rye was the most important crop especially in mountainous areas. Rye was used to make flour and bread that was able to be preserved for a long time (for several months). The very hard bread was cut with a particular tool similar to the cutter which we use to cut the sheets of paper. The bread was made twice a year, because here in the valley, with predominant meadows and pastures, the fire-wood was missing. As remembered by old farmers, the traditional landrace of rye had only two rows and was cultivated until the 1960s. Nowadays this old landrace has disappeared and it also seems not to be present in the gene banks. Today the rye has been replaced by triticale. As in other areas, rye was grown also mixed with wheat (called 'barbaric'), in the sunny slopes (locally called 'Adrech'). The rye, being taller than wheat, was more easily exposed to wind forces causing lodging problems if not adequately protected. For this purpose local farmers used branches of beech. The fertilizing of fields was done with the donkey that carried the manure within the 'banestre' (special baskets used for this purpose). All the details of local agricultural techniques can be seen in the famous museum of Coumboscuro. Buckwheat (Fagopyrum esculentum Moench) was also cultivated, together with broad-beans, lentils, common beans and a landrace of cowpea (Vigna unguiculata (L.) Walp.) with a black eye around the hilum. In the past three old landraces of potatoes were widely grown: i) a red tuber type (called 'ciarda' in Provencal); ii) a white tuber type (called 'Piatlina' in Provencal; iii) an oblong tuber type (called 'patata del giari' in Provencal, 'potato of mouse' in English). Today the cultivation of these old potatoes has been abandoned (mainly for virus and low yield problems) and they have been replaced by modern cultivars. Last samples were collected in the countryside of the Valloriate village where a local farmers' association is trying to multiply and exploit them as typical local product.

\subsubsection{Stura Valley}

Stura valley is one of the longest and most picturesque Occitan valleys, an ancient Roman road towards Provence and nice area across the 'Colle della Maddalena' (1996 m.a.s.l.) and the 'Colle della Lombarda' (2351 m.a.s.1.). The Occitan is still spoken widely throughout the territory until at the entrance to 'Borgo San Dalmazzo' town. In the mountain villages the 'langue d'oc' is among the most archaic and best preserved languages of the entire Alpine 
Occitan area.

The best typical product in the Stura valley is the lamb 'Sambucano', belonging to the autochthonous race of sheep 'Sambucana'. Very valuable and well-known are the dairy products obtained from its milk and the wool. Transhumance was one of the most frequent activities. This old job is well documented in the 'Ecomuseo della pastorizia' (eco-museum of sheep-farming) at Pontebernardo, a hamlet of Pietraporzio (CN).

For centuries, the chestnut has been called the 'bread of the poor'. Also in this valley the fruit represented a basic food of the mountaineers. Nowadays in Stura valley this product is still, for many families, an interesting integration of income and therefore many residents of the valley devote time and care to cleaning chestnut woods to ensure a good harvest (Canobbio et al., 1997).

Today the last Sunday in October at Vinadio town the traditional 'Fair of Saints' is held. Until the eighties of last century this fair revolved around the sales of potatoes ('bòdis' in Occitan), cattle and sheep. Later it focused on the 'Sambucana Sheep exhibition', together with other actions to enhance the traditions of the pastoral world, e.g. the tasting of 'Sambucano lamb' according to various local recipes.

The knowledge of the mountain paths favored smuggling. The main products being smuggled were rice, tobacco and salt; this last one was very cheap but resold in the valleys fifteen to twenty times more expensive. The 'Valle Stura' Mountain Community has dedicated a museum to smuggling, sited at Ferriere (1900 m.a.s.1.).

The traditional 'Cold Fair' is organized in early December at 'Borgo San Dalmazzo'. It was founded by Emanuele Filiberto back in 1569. It is so called because it is the last festive occasion before winter. The fair has become very renowned for tasting and sale of the white snail (Helix Pomatia Alpina) whose white meat is highly appreciated by gourmets. This snail has its natural habitat in the nearby mountain valleys. Today it is bred and cooked in various more or less traditional recipes.

\subsubsection{Collected Material (in Piedmont)}

Farms are mainly localized in the more favored areas, usually the entrance of the valleys most accessible and less subject to logistical problems. Diversified and mixed crops are accompanied by fruit-trees production. Permanent forage crops to support livestock farming are locally very important.

In Piedmont 30 accessions were collected of which 7 cereals, 13 pulses, 8 vegetables and 2 of other species. In particular the following cereals were found: buckwheat ( 1 accession), rye (2 acc.), spelt ( 2 acc.) and maize ( 2 acc.). Buckwheat (called 'fourmenton' in Grana valley) is a traditional cereal, more important in the past than today; at Pamparato town $(\mathrm{CN})$ in November the feast of 'grano saraceno e della castagna bianca' ('buckwheat and white chestnut') is famous.

Two old landraces of rye were collected. Formerly this crop was more common than wheat. As a matter of fact, wheat was destined for the higher classes. The two types of cereal 
actually constituted different products: 'white bread', made with wheat, considered luxury food, was for gentlemen, while the 'black bread', made with rye or other cereals, was food of the peasants and serfs. Chabrol (1994), who was traveling in the territories of the department on foot or by donkey, often asked for 'white bread' in the villages of the hills and mountains, reachable only through very steep paths, but the answer was always the same: 'it was not in such houses he could find it'. Named 'vile cake' in France and in Italy, the 'black bread' is still popular in Central and Northern Europe. The 'black bread' could be made from spelt or mixtures of other cereals, or from barley. This last bread was considered the worst of all because it was heavy and indigestible; it was a good food only in extreme cases, for famine times, or only useful for purging or fattening the horses (Le Roy Ladurie, 1970).

During the mission no landraces of barley were found. In Provence and Langue d'oc in particular, at the end of the Middle Ages barley cultivation was replaced by wheat and later by rye, too; therefore, the continental system wheat-rye-oats took the place of the traditional barley-wheat rotation (Quaini, 1983, p. 179). Barley and wheat were the two major cereals of ancient Mediterranean area (Le Roy Ladurie, 1970). The medieval barley was a cereal not only good for porridge but also an authentic cereal for bread and raw material for the 'polenta'. The dry and Mediterranean climate is excellent for barley, and the inhabitants of the regions facing the Mediterranean sea are used to growing it, while in the north and west, in the high lands of Alps and the mountains of Provence, the mountaineers cultivate rye and oats since immemorial times. The two-year rotation with wheat and barley [called 'orzo invernengo' (winter barley) or 'orzo precoce' (early barley)] is specifically Mediterranean, while in mainland France the rotation with wheat and rye, was practiced instead and further north, the rotation with winter wheat, oats and spring barley (Le Roy Ladurie, 1970).

Two local populations of maize were collected. The spread of maize in Piedmont, compared with Lombardy and Veneto, is rather later. 'Meliga' the folk name of maize in Piedmontese dialect, means sorghum not maize. Maize began to spread from the second half of the XVIII, and only by early XIX century did it gradually start to replace rye in the feeding of the poorest farmers. Chabrol (1994) reported that in the surroundings of Ceva and Acqui villages the cultivation of maize is less susceptible than wheat to diseases and more resistant to damages by wind, rain and hail. Furthermore, all parts of the plant are useful and the costs of planting are almost nil. The cultivation of maize, very much preferred by farmers, has the only drawback to impoverish a bit the soil, and it was noted that since its spread in the two villages, the population grew and emigration, which always occurred after the famine caused by hail, was greatly diminished (Costantini, 1976).

The 13 pulses collected belong to common beans ( 8 accessions), runner beans ( 2 acc.), cowpea (1 acc.) and lentil (1 acc.). A wide variation was recorded, mainly in the Cuneo area, for the legumes some of which are very traditional and already collected and stored in the genebank of the University of Turin. For this reason only some 'garden-races' (sensu Zeven, 1998) were gathered. The most traditional landraces of common bean are: "Regina di Boves", "Regina rossa di Boves", "Regina di Centallo", "Regina rossa di Centallo", "Regina di Roccavione", "Regina precoce di Roccavione", "Borlotto di Entracque", "Borlotto gigante di Cuneo", "Borlotto sanguigno", "Bianco di Bagnasco", "Del Burro", "fagiolo Billò" (or 


\section{MInstitute Macrothink $_{\text {Int }}$}

"Lamon di Cuneo"), "Lamon di Feltre", "Lamon gigante", "Lamon scarlatto", "Lingua di fuoco", "Piattella", "Rampicante di Vigevano", "Rampicante scarlatto" (or "Stregone"), "Rampicante scarlatto bianco" (or "Stregone bianco"), "Rimini", "Saluggia", "Scozzese a baccello bianco", "Scozzese striato", "Super Lamon" and "Toscana". The "fagiolo bianco di Spagna" is a well known landrace of runner bean (Phaseolus coccineus L.) cultivated in the area of Cuneo.

The 8 accessions of vegetables collected were: tomato (2 acc.), eggplant (1 acc.), garlic (1 acc.), pepper (1 acc.), cucumber (1 acc.), zucchini (1 acc.) and lettuce (1 acc.). Also for these crops growing in the Cuneo province an important safeguarding activity was started jointly by the Piedmont Region and the University of Turin (Marelli, 2011, see also the web site: http://www.regione.piemonte.it/agri/area_tecnico_scientifica/biodiversita/germoplasma.htm).

Some of the most known pepper (Capsicum annum L.) landraces are: "peperone braghese", "peperone corno", "peperone di Cuneo", "peperone cornetto verde" and "peperone quarantino".

One sample of the ancient variety of garlic "Aglio di Caraglio", highly threatened with extinction (Laghetti et al., 2012) was collected. This material will be maintained in IPK's living collection and, at some later stage, it might be transferred to cryo-conservation. Formerly this sweet landrace of garlic was traditionally grown in home gardens and, in case of overproduction, sold at farmers' markets. Later its cultivation has disappeared over time due to its too delicate aroma. As a matter of fact people preferred garlic characterized by strong and persistent flavor. In popular belief, stronger garlic, more effective was in combating diseases (e.g. influenza and cold). This landrace has been recently re-evaluated by one local consortium and cultivated by fifteen farms of Caraglio. The P.A.T. mark (Traditional Italian Food Products) has been already requested for it.

Traditional are also the "porro di Cervere" leek (Allium porrum L.), the "rapa rossa di Cervere" (or "viola di Cervere") turnip (Brassica rapa L.), the "zucca lunga" cucumber and the potatoes: "Piatlina di Cesana", "Piatlina di Pragelato", "Piatlina di Entracque", "patata del bur" (or "Trifulot del bur") and "Quarantina di Entracque".

In a farm of Cavaliggi, a hamlet of Valgrana $(\mathrm{CN})$, a rare cultivation of citron melon (Citrullus lanatus (Thunb.) Matsum. et Nakai subsp. lanatus var. citroides (Bailey) Mansf. ex Greb.) was found and collected. This crop is traditional in Corsica (Laghetti and Hammer, 2007) and uncommon in Italy where it was found in Liguria by Laghetti et al. (2012). In the same farm an uncommon cultivation of a 'blue potato' was observed as in a recent collecting mission (Laghetti et al., 2012). In another organic/biodynamic farm of the same area a number of unusual crops were cultivated mainly for remote sales as an old pink Swiss variety of tomato 'Rosa di Berna' characterized by six sepals, an excellent taste and high yield.

\subsubsection{Occitan area (Guardia Piemontese)}

'Guardia Piemontese' ('La Gardia') town (the only Occitan municipality in centre-south Italy) is located in province of Cosenza (Calabria region) with about 1,558 inhabitants (Fig. 11). The town (514 m.a.s.l.) was founded in the thirteenth century by a group of Waldenses 


\section{MInstitute Macrothink $_{\text {Int }}$}

coming from the valleys of Piedmont (A.A. V.V., 1986). The predominant activity of that Waldensian community, settled in that territory to escape poverty and religious intolerance, was the cultivation of fertile land, entrusted by the local feudal lords (Stancati, 1984).
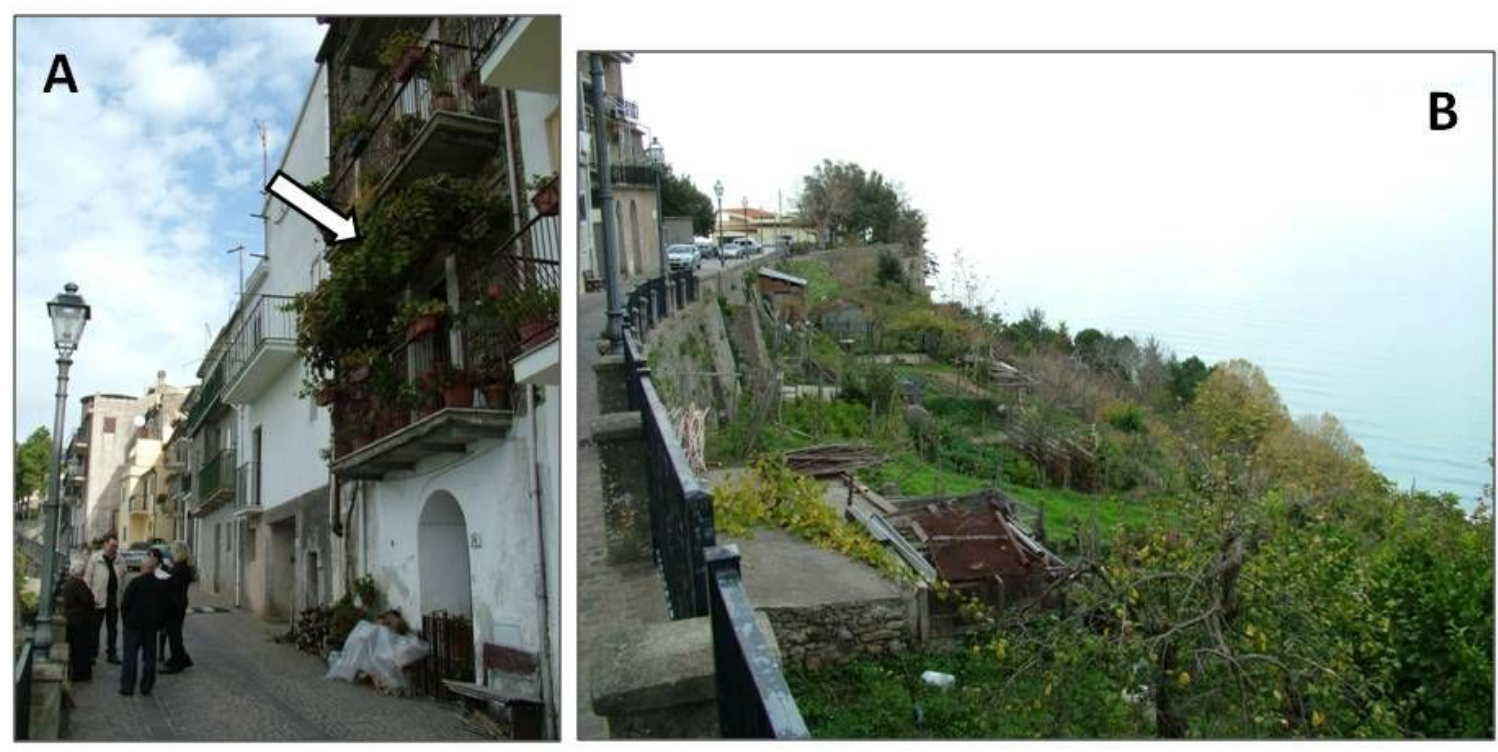

Figure 11. (A) Interviewing some farmers of Guardia Piemontese whose houses has typically balconies with plants of grape (Vitis vinifera) as ornamental (see white arrow); (B) left side of photo 'A' showing some family gardens facing the sea

The most common type of cultivation was that of the 'medieval garden', usually situated on the periphery of the village ('òrts d'après') near the house of farm-worker and the stable that included within it, vegetables, fruit trees and officinal plants. This type of garden was very widespread in the area and of important economic reality. Always fenced or otherwise enclosed, it was the only part of the cultivated land that benefited from the continued presence of man in terms of quality and quantity of work (Stancati, 1984). In fact, it played a leading role in the food budget of the peasant family taking into account that the yield of vegetables was much higher than that of cereals, thanks to the easier fertilizer due to the proximity of the stable to the house, but also for the better care dedicated to it by the farmer. As a matter of fact, the rural food was based mainly on garden products, rather than those arising from the fields of cereals that were destined to other purposes (seed, fees to the landowner). In the 'medieval garden' officinal plants were cultivated almost exclusively as flavorings; the growing of fruit trees not very widespread in the Middle Ages as autonomous cultivations, it was not an activity undertaken with particular interest by farmers due to increased space requirements, difficulties of cultivation and storability. In most Occitan areas in Italy, the process of rural depopulation due to emigration and the consequent abandonment of the fields by farmers have provoked strong crop genetic erosion (Laghetti et al., 2012). The same phenomenon was recorded in the territory of Guardia Piemontese, with the disappearance of most of the landraces formerly cultivated here, only very few of which are still present. In fact, in the past, several varieties of legumes, vegetables, cereals and fruit trees were grown. In particular, the food of the population of this town was based primarily 
on the use of common beans that played a leading role among the pulses, which were used in several varieties. Chickpeas and broadbeans were mostly used to feed livestock, except for the large seeded varieties consumed for food; lentils formerly were sown, as nitrogen fertilizer, with wheat and rarely became part of the food. Among the vegetables, yellow squash was grown in large quantities, more than zucchini, because it was used both for human consumption and for livestock feeding. Tomato, especially an ancient variety, called "cuore di bue" ('ox heart') was used both fresh and for the preparation of the sauce. The peppers, eggplants, potatoes and cucumbers were also used as important elements of the local kitchen. The cereals, because of the morphology of the mountainous territory, were less cultivated because they required greater space and their yield was much lower than that vegetables. Wheat, maize, barley, oat and rye were grown, though unfortunately no trace remained.

During the mission only 5 landraces were found and collected at Guardia Piemontese (Table 1) i.e. common bean (1 acc., called "Faisòls embiscats"), tomato (1 acc., "Pomodor"), eggplant (1 acc., "Melanciana”), zucchini (1 acc., “cord”) and cucumber (1 acc., “cetriol”).

The old landraces of cereals instead, are completely extinct, together with information about their folk names and uses, owing to the disappearance of the elderly population. All other information has been obtained thanks to the local 'Occitan Linguistic Desk'.

\subsection{Other Areas}

Several other zones were crossed outside the main target areas of the mission (linguistic districts). In some cases interesting landraces were found (Table 1), like an ancient landrace of bread wheat still cultivated only by an old farmer at 'Cairo Montenotte' (province of Savona in Liguria region).

In the countryside of 'Cassano delle Murge' (Apulia region) the following material was collected: five samples of the "cece nero" ('black chickpea', see Fig. 12), two types of the "lenticchia nera" ('black lentil' - Lens culinaris), the "cicerchia" (Lathyrus sativus), a population of hyacinth bean (Lablab purpureus), and two rare purple podded peas (Pisum sativum var. arvense).

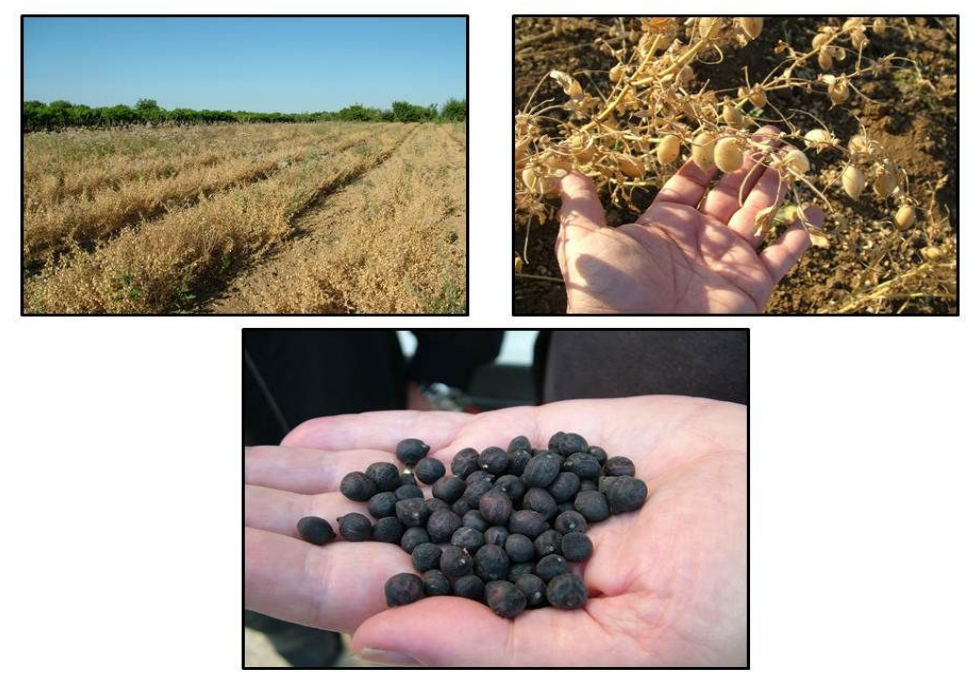


Figure 12. A traditional landrace of black chickpea from 'Cassano delle Murge' (Apulia region)

In the Calabria region the typical common beans from 'Cortale' ("reginella bianca", "reginella gialla", "cannellina bianca", "cocò gialla" and "cocò bianca") and 'San Pietro' ("San Pietro", "posa", "insalata lunga", "fagiolino rosso", "quarantina", "insalata miscelata" and "povarella") areas (Piergiovanni et al., in press) were sampled. Other old local varieties of common bean, out of Cortale and San Pietro areas, such as "milanese", "viteralese", "rizza", "russa janca", "monachella scura", "a pisello", "cannellino" and "petrise" were sampled. In addition, the chickpea "monachella" and other typical Calabrian pulses were collected (Table 1). Details on the grain legume landraces grown in Calabria are reported in ARSSA (2010). The district of Decollatura (CZ) is traditionally rich of vegetable landraces and some of them were gathered e.g. the pepper "pizzitano", the turnip "locale", the savoy cabbage (Brassica oleracea L. var. sabauda L.) "verza antica", the tomato "belmonte calabro", the cucumbers "sorbello" and "villotta" and other crops reported in Table 1. In this same zone and for the first time, a cultivation of African eggplant (Solanum aethiopicum L.) was observed outside Rotonda district, the unique growing place known in Italy (Laghetti et $a l .$, 1995). In the marquisate of Crotone area, the most oriental strip of the region the two old Italian varieties of durum wheat 'Cappelli' and of bread wheat 'maiorca' were found.

Two accessions of the so called 'anice nero di Calabria' ('black anice of Calabria') were collected for its taxonomical classification. This wild species (Pimpinella anisoides Briganti according to our classification) is traditionally collected for its very fragrant seeds used as flavouring for local sweets and commercial liqueurs (Hammer et al., 2000).

\section{Conclusions}

In Italy the Occitan, Franco-Provençal and Croatian linguistic islands still conserve worthy crop genetic resources but as for other ethnic minorities, the traditional customs and idioms are losing importance. In connection with this trend a strong genetic erosion and extinction of landraces are also ongoing so that their safeguarding both ex situ and in situ is an urgent task. One of the strategies to promote the territory lies in the enhancement of the typical local food production and in the support of facilities for processing and marketing outside the strictly local area. Also the high quality agriculture can contribute to the socio-economic development of the area. To the quality and genuineness of products, is connected their processing and working with traditional methods, through techniques always practiced there. In addition, for all studied areas, a greater interest and awareness by the regional agricultural departments is necessary.

About the crop genetic erosion, the aim of this study has considered only the investigation and detection of its trend. The quantitative data on genetic erosion in the Occitan, Croatian and Franco-Provençal linguistic islands will be reported within a general book (in preparation) on 'Agrobiodiversity in all linguistic islands in Italy'. In that book the same criterion used by Hammer and Laghetti (2005) to measure genetic erosion will be used.

With regards to the availability of germplasm, the material collected is being deposited in the 
gene bank of Bari for further classification and characterisation. After its multiplication, it will be ready for distribution to the scientists. Further data and details about this collecting mission are reported in the exploration registers and internal database by IGV.

\section{Acknowledgements}

The authors are pleased to thank the following people for their valuable help, assistance and donations of seed samples during the mission in the study areas:

Franco-Provençal area

vice mayor of Faeto geom. Giovanni D'Onofrio;

miss Virginia Carosielli of 'sportello linguistico' (linguistic desk) of Faeto;

Mr. Mario Comparillo (farm 'contrada Niolla');

Families: Tangi Carmelino, Girardi Pasquale, Girardi Carmelina, Girardi Antonio

Croatian area

Mrs. Paolina Ferrante and Mr. Antonio Ferrante (San Felice del Molise)

Prof. Giovanni Piccolo (Acquaviva Collecroce)

Mr. Aurelio Bartolini (Montemitro)

Mrs. Elisa Bartolino of 'sportello linguistico' (linguistic desk) of Montemitro

Occitan area

Dr. Anna Arneodo, her family and friends (Dr. Renato Lombardo and Dr. Lucio Alciati) for the important historical and agricultural information, bibliographic and seeds material about the area of Sancto Lucio de Coumboscuro.

The Ethnographic Museum at 'Sancto Lucio de Coumboscuro' in Grana valley managed by the 'Coumboscuro Centre Provençal'; this museum stores the most extensive ethnographic collection of the Western Alps, a crossroads and a meeting place between material culture, language and culture of Provence.

Mr. Mauro Giordano, a young farmer of Caraglio who has started to search and cultivate ancient landraces, mainly of cereals.

Mrs. Roberta Capanna (and her daughter Stefania) owner of an interesting Organic/Biodinamic farm at Cavaliggi an hamlet of Valgrana $(\mathrm{CN})$ where they cultivate and sell many uncommon crops.

'Filatoio Rosso' foundation and 'Marco Valdo' cultural association for technical and historical information on silk manufacturing in Grana valley; in that occasion it was very appreciated the visit to the famous 'red spinning machine' of Caraglio built in 1676.

Mr. Pessione Dino was very kind to show us the nice and interesting ethnographic museum 'Vita d'isì' at Colletto an hamlet of Castelmagno village, dedicated to the memory of 
everyday life of this area.

Dr. Baudino Michele responsable of 'Centro Sperimentale Orticolo' (CReSO S.C.a r.l.), Boves $(\mathrm{CN})$

Dr. Berardi Luciana curator of 'Museo della canapa e del lavoro femminile' ('museum of hemp and female labour') at Prazzo (CN) in Maira valley.

Mr. Martini Stefano responsable of 'Ecomuseo della pastorizia' (eco-museum of sheep-farming) at Pontebernardo an hamlet of Pietraporzio $(\mathrm{CN})$ in Stura valley.

Mr. Rocchetti Vincenzo, mayor of Guardia Piemontese.

Dr. Tundis Angelica and Mrs. Primavera Silvana of 'Sportello Linguistico Occitano' at Guardia Piemontese.

Other areas

Dr. Sirianni Pietro, vice-director of 'Coldiretti' in Calabria.

Mr. Talarico Gerardo nurseryman and farmer of Decollatura (CZ).

Mr. Eustachio Racano, Mr. Conti Pietro and his wife Mrs. Fatiguso Angela of Cassano delle Murge (BA) for their valuable donation of local pulse germplasm

\section{Sponsoring}

Part of this research was supported through the project 'Implementazione nazionale del trattato internazionale FAO-RGV' financed by MiPAAF, the Italian Ministry

\section{References}

A. A. V. V. (1986). I Calabro-Valdesi, guida ai luoghi storici. Torino.

ARSSA. (2010). Le leguminose da granella in Calabria. Rende (CS).

Aimar U. (1978). Val Grana - Etimologia del nome, lo stemma, le origini storiche. L'tò Almanach.

Baudino M, Costamagna F \& Frati S (curators). (2011). Antichi ortaggi del Piemonte. Salvaguardia, recupero dall'erosione genetica e valorizzazione. Regione Piemonte (ed.), Cuneo.

Marelli A (curator). (2011). Recupero e caratterizzazione di vecchi ecotipi autoctoni piemontesi di fagiolo da granella. Regione Piemonte (ed.), Cuneo.

Bernard JL. (1992). Nosto modo. Testimonianza di civiltà provenzale alpina a Blins (Bellino). p. 29, L.C.L. Busca, Cuneo.

Breu W. (1990). Sprache und Sprachverhalten in den slavischen Dörfern des Molise (Süditalien). In: Breu W (curator), Slavistische Linguistik 1989. München, 35-69.

Canobbio S, Genre A, Martini S \& Telmon T (curators). (1997). 'La lengo de ma maire'. 
Tradizione e lingua nella valle Stura di Demonte. 'Comunità montana valle Stura di Demonte' (ed.), Demonte (CN).

Casalis G, 1842. Dizionario Geografico Storico Statistico Commerciale degli Stati di Sua Maestà il Re di Sardegna. Vol. X. G. Maspero Libraio, Torino.

Chabrol G. (1994). Statistica delle province di Savona, Oneglia, di Acqui e di parte della provincia di Mondovì che formavano il Dipartimento di Montenotte. Assereto G, (curator), Voll. II, pp. 188-189, Comune di Savona, Savona.

Costantini C. (1976). Comunità e territorio in Liguria. L'inchiesta dell'Instituto Nazionale (1799). In: A.A.V.V., Territorio e società nella Liguria Moderna. Studi di storia del territorio, Nuova Italia, Firenze.

De Salvio A. (1908). Relics of Franco-Provençal in Southern Italy. Publications of the Modern Association of America, XXIII,47-79.

Di Tizio A, Łuczaj Ł, Quave C L, Redžić S \& Pieroni A. (2012). Traditional food and herbal uses of wild plants in the ancient South-Slavic diaspora of Mundimitar/Montemitro (Southern Italy). Journal of Ethnobiology and Ethnomedicine. 8-21. http://dx.doi.org/10.1186/1746-4269-8-21

Ghersi A \& Ghiglione G. (2012). Paesaggi terrazzati. I muretti a secco nella tradizione rurale ligure. Il Piviere (ed.), Alessandria,156

Ghiglione G \& Leone FG. (2001). Il ruolo delle "fasce" in Liguria. Olivo \& Olio, Calderini Edagricole (ed.), 1-2,64-70, Bologna

Ghiglione G. (2005). Il territorio in Liguria: il caso delle "fasce”. In: Genova una "porta" del Mediterraneo. Gallinari L (curator), CNR - ISEM (ed.), Genova: 913-950.

Gilles P. (1643). Histoire ecclesiastique des églisese reformées recueillies en quelques Valées de Piedmont, autrefois appelées Vaudoises. Paris, 19.

Guarrera PM, Lucchese F \& Medori S. (2008). Ethnophytotherapeutical research in the high Molise region (Central-Southern Italy). Journal of Ethnobiology and Ethnomedicine, 4-7.

Hammer K, Laghetti G, Cifarelli S \& Perrino P. (1991). Collecting in northeastern Italy using he indicator-crop method. FAO/IBPGR Plant Genetic Resources Newsletter, 86, 39-40.

Hammer K, Knüpffer H, Laghetti G \& Perrino P. (1992). Seeds from the past. A catalogue of crop germplasm in South Italy and Sicily. Germplasm Institute of C.N.R. (ed.), Bari, Italy, pp. $\mathrm{II}+173$.

Hammer K, Laghetti G, Cifarelli S, Spahillari M \& Perrino P. (2000). Pimpinella anisoides Briganti. Genetic Resources and Crop Evolution, 47(2), 223-225. http://dx.doi.org/10.1023/A:1008717810460

Hammer K \& Laghetti G. (2005). Genetic erosion - examples from Italy. Genetic Resources and Crop Evolution, 52(5), 629-634. http://dx.doi.org/10.1007/s10722-005-7902-x 
Hammer K, Miceli F, Cifarelli S \& Laghetti G. (2007a). Sauris (Zahre), a cultural and linguistic island in Carnia (Italy). In: Procc. of the XVII Eucarpia Genetic Resources Section Meeting 'Plant Genetic Resources of Geographical and "other" islands. (Conservation, Evaluation and Use for Plant Breeding). 30 March -2 April 2005, Castelsardo, Italy. Bullitta S. (ed.), CNR-ISPAAM sez. Sassari, Italy, 185-192.

Hammer K, Cifarelli S \& Laghetti G. (2007b). Linguistic islands and plant genetic resources the case of German-speaking villages in northern Italy. In: Procc. of the $18^{\text {th }}$ Eucarpia Genetic Resources Section Meeting 'Plant Genetic Resources and their Exploitation in the Plant Breeding for Food and Agriculture'. May 23-26, 2007, Piešt'any, Slovak Republic, p.32.

Hammer K, Laghetti G \& Pignone D (eds.). (2011). Linguistic Islands and Plant Genetic Resources - The Case of the Arbëreshë. ARACNE, Rome, ISBN 978-88-548-3958-8

Hammer-Spahillari M, Laghetti G, Cifarelli S \& Hammer K. (2007). Ethnographic islands: the case of the Arbëreshë. In: Procc. of the XVII Eucarpia Genetic Resources Section Meeting 'Plant Genetic Resources of Geographical and "other" islands. (Conservation, Evaluation and Use for Plant Breeding)'. 30 March -2 April 2005, Castelsardo, Italy. Bullitta S. (ed.), CNR-ISPAAM sez. Sassari, Italy, p.173-183.

Isoardi F. (2008). Valgrana. Il mio paese. Comunità montana 'ValleGrana' (ed.), Peveragno $(\mathrm{CN})$.

Laghetti G, Hammer K \& Perrino P. (1993). Collecting in northwest Italy. FAO/IBPGR Plant Genetic Resources Newsletter, 91/92-23.

Laghetti G, Hammer K, Brandi M, Cerbino D, Olita G \& Perrino P. (1995). Ritrovamento di una coltivazione di melanzana africana. Infor. Agr. LI, 39,52.

Laghetti G, Xhuveli L, Perrino P, Olita G \& Hammer K. (1998). Collecting crop genetic resources in Italian towns of Albanian origin: Basilicata region. Plant Genetic Resources Newsletter, 114, 29-34.

Laghetti G, Perrino P, Cifarelli S, Spahillari M \& Hammer K. (2002). Collecting of landraces and wild relatives of cultivated plants in Ponziane islands and Tuscan archipelago, Italy. Plant Genetic Resources Newsletter, 131, 55-62.

Laghetti G, Perrino P, Cifarelli S, Bullitta S \& Hammer K. (2003). Collecting plant genetic resources in Italy, 2001. Plant Genetic Resources Newsletter, 136, 23-30.

Laghetti G \& Hammer K. (2007). The Corsican citron melon (Citrullus lanatus (Thunb.) Matsum. et Nakai subsp. lanatus var. citroides (Bailey) Mansf. ex Greb.) a traditional and neglected crop. Genetic Resources and Crop Evolution, 54(4), 913-916. http://dx.doi.org/10.1007/s10722-007-9220-y

Laghetti G, Pignone D, Cifarelli S, Martignano F, Falco V, Traclò BRG \& Hammer K. (2008). Agricultural biodiversity in Grecìa and Bovesìa, the two Griko-speaking areas in Italy. Plant Genetic Resources Newsletter, 156, 43-49 
Laghetti G, Pignone D, De Lisi A, Cifarelli S, Faslia N \& Hammer K. (2011). Collecting crop genetic resources in Italian towns of Albanian origin across the Molise, Calabria and Sicily

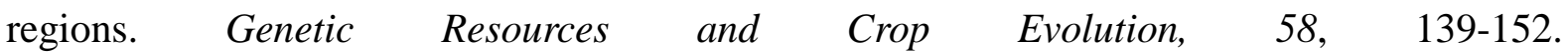
http://dx.doi.org/10.1007/s10722-010-9622-0

Laghetti G, Ghiglione G, Miceli F, Cifarelli S, Pignone D \& Hammer K. (2012). Collecting crop genetic resources in two Italian linguistic (Occitan and Ladin) islands and west Liguria with historical and ethnobotanical notes. International Journal of Biodiversity and Conservation, 4(2), 54-70.

Le Roy Ladurie E. (1970). I contadini di Linguadoca. Laterza (ed.), Bari

Melillo M. (1959). Intorno alle probabili sedi originarie delle colonie francoprovenzali di Celle e Faeto. Revue de Linguistique Romaine, XXIII,1-34.

Melillo M. (1974). Donde e quando vennero i francoprovenzali di Capitanata. Lingua e storia in Puglia; Centro di Studi pugliesi (Siponto): I quaderni della regione, 1,80-95.

Miceli F, Dalla Costa L, Laghetti G \& Hammer K. (2007). Resia: A deep-rooted Slavic Community in the Italian Alps and its Garlic Landrace. In: Procc. of the XVII Eucarpia Genetic Resources Section Meeting "Plant Genetic Resources of Geographical and "other" islands. (Conservation, Evaluation and Use for Plant Breeding)'. 30 March -2 April 2005, Castelsardo, Italy. Bullitta S. (ed.), CNR-ISPAAM sez. Sassari, Italy, 257-259.

Mondino GP. (1965). La vegetazione della Valle Grana (Alpi Cozie). Allionia, boll. Istit. and Orto Bot. of University of Turin, 11,183-264.

Montanari M. (2000). La fame e l'abbondanza. Storia dell'alimentazione in Europa. Laterza (ed.), Bari

Perillo FS. (1985). La situazione attuale dei croati in Molise. In: Le minoranze etniche e linguistiche. Palermo.

Perrino P, Hammer K \& Hanelt P. (1981). Report of travels to South Italy 1980 for the collection of indigenous material of cultivated plants. Kulturpflanze 29, 433-442.

Piccoli A. (2009). L'ambiente, la vita e le colture tradizionali ad Acquaviva Collecroce. Larino (CB).

Piergiovanni AR, Maruca G \& Lioi L. (2012). Caratterizzazione biochimica di germoplasma di fagiolo mantenuto on-farm in Calabria. In: Procc. of the V Convegno Nazionale Piante Mediterranee, Bari (in press)

Pieroni A, Giusti ME, Münz H, Lenzarini C, Turković G \& Turković A. (2003). Ethnobotanical knowledge of the Istro-Romanians of Žejane in Croatia. Fitoterapia 74(7-8),710-719. http://dx.doi.org/10.1016/j.fitote.2003.06.002

Pieroni A \& Giusti ME. (2008). The Remedies of the Folk Medicine of the Croatians Living in Čičarija, Northern Istria. Coll Anthrop, 32, 623-627. 


\section{Macrothink}

Journal of Biology and Life Science ISSN 2157-6076 2013, Vol. 4, No. 1

Pirozzoli A \& Pirozzoli N. (1983). I mulini ad acqua dell'alta valle del Celone. Centro Grafico Meridionale (ed.), Foggia.

Quaini M. (1983). Per la storia del paesaggio agrario in Liguria. Camera di Commercio, Industria e Artigianato di Savona (ed.), Savona

Rešetar M. (1911). Le colonie serbocroate nell'Italia Meridionale. Amministrazione Provinciale Campobasso (ed.), Campobasso, (translated in Italian from German in 1997).

Rey O. (2006). 'l chinebbu (la canapa). Piedmont Region (ed.), Salbertrand (To).

Stancati E. (1984). Gli Ultramontani. Storia dei Valdesi in Calabria. Cosenza.

Stouff L. (1970). Ravitaillement et alimentation en Provence aux XIV et XV siecles, Paris.

van Gennep A. (1990). Les Alpes Traditionelles. Curandera Voreppe (ed.), Tome 1,191 pages.

Zeven AC. (1998). Landraces: a review of definitions and classifications. Euphytica, 104(2), 127-139. http://dx.doi.org/10.1023/A:1018683119237

Zohary D \& Hopf M. (1988). Domestication of Plants in the Old World. Oxford.

\section{Copyright Disclaimer}

Copyright reserved by the author(s).

This article is an open-access article distributed under the terms and conditions of the Creative Commons Attribution license (http://creativecommons.org/licenses/by/3.0/). 